\title{
A DEFENCE OF THE MARGIN OF APPRECIATION AND AN ARGUMENT FOR ITS APPLICATION BY THE HUMAN RIGHTS COMMITTEE
}

\author{
DOMINIC MCGOLDRICK*
}

\begin{abstract}
The margin of appreciation (MoA) has become the central conceptual doctrine in the institutional and jurisprudential architecture of the European Convention on Human Rights (ECHR). This article critiques the existence and operation of the MoA within the ECHR system and defends its use. It is submitted that as each of the central justifications for the MoA under the ECHR applies equally to the International Covenant on Civil and Political Rights (ICCPR), so the doctrine should be applied by the Human Rights Committee.
\end{abstract}

Keywords: consensus, European Court of Human Rights, Human Rights Committee, margin of appreciation, universality of rights.

\section{INTRODUCTION}

The margin of appreciation (MoA) has become the central conceptual doctrine in the institutional and jurisprudential architecture of the European Convention on Human Rights (ECHR). ${ }^{1}$ To a limited degree it has spread to some other human rights institutions ${ }^{2}$ and to other international decision-making bodies. ${ }^{3}$

* Professor of International Human Rights Law, University of Nottingham, dominic. mcgoldrick@nottingham.ac.uk. I am grateful to Sangeeta Shah and to two anonymous reviewers for their comments.

1 For recent examinations of the MoA see D Spielmann, 'Allowing the Right Margin the European Court of Human Rights and the National Margin of Appreciation Doctrine: Waiver or Subsidiarity of European Review?' (2012) 14 CYELS 381 (updated at <http://www.echr.coe.int/ Documents/Speech_20140113_Heidelberg_ENG.pdf $>$ ); A Legg, The Margin of Appreciation in International Human Rights Law Deference and Proportionality (OUP 2012); Y Arai-Takahashi, The Margin of Appreciation Doctrine and the Principle of Proportionality in the Jurisprudence of the ECHR (Intersentia 2002); Y Arai-Takahashi, 'The Margin of Appreciation Doctrine: A Theoretical Analysis of Strasbourg's Variable Geometry' in A Follesdal et al. (eds), Constituting Europe (CUP 2013) 62.

${ }^{2}$ See H Cullen, 'The Collective Complaints System of the European Social Charter: Interpretative Methods of the European Committee of Social Rights' (2009) 9 HRLRev 61. The UN Committee on Economic, Social and Cultural Rights (CESCR) has stated that, 'Every State party has a margin of discretion in adopting appropriate measures in complying with its primary and immediate obligation to ensure the equal right of men and women to the enjoyment of all their economic, social and cultural rights' (emphasis added); (2005) GC 16, para 32.

3 See Y Shany, 'Towards a General Margin of Appreciation Doctrine in International Law' (2005) 16 EJIL 907; J Arato, 'The Margin of Appreciation in International Investment Law' 
Yet one of the great intellectual mysteries in international human rights law remains - why has the Human Rights Committee (HRC) under the International Covenant on Civil and Political Rights (ICCPR) not only not invoked the concept of the MoA, but explicitly rejected it. This article critiques the existence and operation of the MoA within the ECHR system and defends its use. It is submitted that as each of the central justifications for the MoA under the ECHR applies equally to the ICCPR, so the doctrine should be applied by the HRC.

Following these introductory comments, Section II examines the concept and use of the MoA and, in particular, the relationship between the MoA and the Standard of Review. Section III assesses the role of consensus or the lack thereof in determining the MoA. Section IV considers the various justifications advanced for using the MoA. Section V assesses various critiques of the MoA. Section VI raises the issue of the non-use of the MoA by the HRC. Section VII analyses a series of jurisprudential similarities and differences between the European Court of Human Rights (ECtHR)/ECHR and the HRC/ICCPR and considers whether they justify or explain the nonuse of the MoA by the HRC. Section VIII considers the development of complementary and conflicting jurisprudence as between the ECtHR and the HRC. Section IX critiques a series of possible explanations for the non-use of the MoA. Section X offers some concluding reflections.

\section{THE CONCEPT OF THE MARGIN OF APPRECIATION}

\section{A. The Concept}

Although the MoA was judicially developed by the European Court of Human Rights (ECtHR) it has now received express affirmation and support from the States parties to the ECHR. The 'Brighton Declaration' on the Future of the ECtHR (2012) 4 contained seven references to the 'margin of appreciation' and six references to 'subsidiarity'. 5 Protocol 15 ECHR (2014) (not yet in force) will add to the Preamble of the ECHR a reference to the principle of subsidiarity and the doctrine of the MoA. Even before Protocol 15 comes into force the ECtHR had stressed the 'crucial importance' of its subsidiary role. ${ }^{6}$

The MoA is not a right of States. It is a doctrine of judicial self-restraint that was developed by the ECtHR and which the States parties have now endorsed. ${ }^{7}$

(2014) VaJIntlL 545. cf E Bjorge, 'Been There, Done That: The Margin of Appreciation and International Law’ (2015) 4(1) CJICL 181.

4 Available at $<$ http://hub.coe.int/20120419-brighton-declaration>.

5 See GL Neuman, 'Subsidiarity' in D Shelton (ed), The Oxford Handbook of International Human Rights Law (OUP 2013) 360.

6 See Stella $v$ Italy, A. 49169/09 and 10 other applications, and Rexhepi v Italy A. 47180/10 and seven other applications (25 Sept 2014).

7 See J-P Cot, 'Margin of Appreciation' in R Wolfrum (ed), 6 Max Planck Encyclopaedia of Public International Law (2013) 1012; F Ni Aolain, 'The Emergence of Diversity: Differences in 
It was originally applied in the context of derogations ${ }^{8}$ but has now spread to the interpretation of the scope of obligations under all of the substantive articles, even obligations under non-derogable ones such as Articles $2^{9}$ and $3,{ }^{10}$ and to the accessory protection against discrimination in Article $14 .{ }^{11}$ In the seminal MoA case, Handyside v UK (1976), the ECtHR explained that,

This margin [of appreciation] is given both to the domestic legislator ('prescribed by law') and to the bodies, judicial amongst others, that are called upon to interpret and apply the laws in force ... The domestic margin of appreciation ... goes hand in hand with a European supervision. Such supervision concerns both the aim of the measure challenged and its 'necessity'; it covers not only the basic legislation but also the decision applying it, even one given by an independent court. ${ }^{12}$

The MoA is most commonly applied in the context of limitations on rights. ${ }^{13}$ It has assumed even more significance as the ECtHR, through its case law, has expanded the scope of ECHR rights through its interpretation of the ECHR as a 'living instrument' 14 and thereby developed the scope of procedural and positive obligations. ${ }^{15}$ With respect to positive obligations the States enjoy a wide MoA in determining the steps to be taken to ensure compliance with the ECHR with due regard to the needs and resources of the community and of individuals. ${ }^{16}$

In assessing whether there exists a pressing social need for the measure in question and, in particular, whether the interference was proportionate ${ }^{17}$ to the legitimate aim pursued, regard has to be had to the 'fair balance' which has to be struck between the relevant competing interests and in respect of

Human Rights Jurisprudence' (1995) 19 FordhamIntlLJ 101. The orthodox view that the MoA doctrine had its origins in French and German law is contested by Bjorge (n 3).

${ }^{8}$ See $A$ and Others $v U K$ [GC], A. 3455/05, para 173.

9 See S Skinner, 'Deference, Proportionality and the Margin of Appreciation in Lethal Force Cases under Article 2 ECHR' (2014) EHRLR 32; Vo v France [GC], A. 53924/00; Lambert v France [GC], A. 46043/14 (5 June 2015).

10 Valiuliene v Lithuania A. 33234/07, 26 March 2013, at para 85 (the choice of the means to secure compliance with art 3 in the sphere of the relations of individuals between themselves is in principle a matter that falls within the domestic authorities' margin of appreciation); Legg (n 1) 204-10.

${ }^{11}$ See S.S. v UK; F.A. v UK, A. 40356/10 and 54460/10 (entitlement to social security benefits); O Mjöll Arnardóttir, 'The Differences that Make a Difference: Recent Developments on the Discrimination Grounds and the Margin of Appreciation under Article 14 of the ECHR' (2014) 14 HRLR 647.

121 EHRR (1979-80) 737, para 48.

${ }^{13}$ See J Kratochvíl 'The Inflation of the Margin of Appreciation by the European Court of Human Rights' (2011) NQHR 324; O Bakircioglu, 'The Application of the Margin of Appreciation Doctrine in Freedom of Expression and Public Morality Cases' (2007) 8 German Law Journal 711.

${ }^{14}$ See N Bratza, 'Living Instrument or Dead Letter - the Future of the ECHR' (2014) EHRLR 116; K Dzehtsiarou, 'European Consensus and the Evolutive Interpretation of the ECHR' (2011) 12 (10) German Law Journal 1730.

${ }_{15}$ See E Brems and J Gerards (eds), Shaping Rights in the ECHR: The Role of the ECtHR in Determining the Scope of Human Rights (CUP 2013).

${ }_{16}$ See Abdulaziz v UK, A. 9214/80, 9473/81, 9474/81 (1985) 7 EHRR 471, para 67.

17 Spielmann (n 1) (updated version), observed that 'the proportionality principle constitutes the strongest bulwark against the over-use of the margin of appreciation doctrine' at 22. See also S Tsakyrakis, 'Proportionality: An Assault on Global Human Rights' (2009) 7 ICON 468. 
which the State enjoys an MoA. ${ }^{18}$ The breadth of the MoA to be accorded to the State can be crucial to the ECtHR's conclusion as to whether the challenged provision struck a fair balance. ${ }^{19}$ In delimiting the extent of the MoA the ECtHR has regard to what is at stake therein. ${ }^{20}$ Where a particularly important facet of an individual's existence or identity is at stake, the MoA allowed to the State will normally be restricted. ${ }^{21}$ So too where measures, such as deprivation of legal capacity, have such an adverse effect on an individual's personal autonomy. ${ }^{22}$ If the process was seriously deficient in some respect, the conclusions of the domestic authorities are more open to criticism. ${ }^{23}$ Significance is also attached to whether the measure deprived the alleged victim of the core contents of a Convention right. ${ }^{24}$

In terms of whether the MoA applies and its width, it will be significant if the relevant law or policy is considered to reflect the 'profound moral views of the people of the state' 25 or 'concerns a question about the requirements of morals' ${ }^{26}$ There will usually be a wide MoA if the State is required to strike a balance between competing private and public interests or competing rights and interests that are protected under the ECHR. ${ }^{27}$ Where ECHR rights deserve equal respect the MoA should in principle be the same irrespective of which party brings the proceedings. ${ }^{28}$

An element to which the ECtHR increasingly directs its attention is whether the national decision-making process, seen as a whole, provides for the requisite

18 See J Christofferson, Fair Balance: Proportionality, Subsidiarity and Primarity in the ECHR (OUP 2009); Schindler v United Kingdom, A. 19840/09 (7 May 2013) (confining the parliamentary franchise to those citizens with a close connection with the UK was fair); Couturon v France, A. 24756/10 (25 June 2015); Chitos v Greece, A. 51637/12 (4 June 2015).

$19 A, B$ and $C$ vreland [GC], A. 25579/05, para 231 (concerning access to abortion); Parrillo $v$ Italy [GC], A. 46470/11 (27 August 2015) paras 183-197 (concerning restrictions on right to donate embryos to scientific research).

20 Şahin v Turkey [GC], A. 30943/96, para 110 (concerning the wearing of Islamic headscarves in educational institutions). cf Parrillo v Italy [GC], A. 46470/11 (27 August 2015) para 174 (right to donate embryos to scientific research is not one of the core rights attracting the protection of art 8 of the Convention did not concern a particularly important aspect of the applicant's existence and identity.)

${ }^{21}$ Evans $v$ UK [GC], A. 6339/05 (2008) 46 EHRR 34, para 77 (concerning an ex-partner's consent for the use of frozen embryos).

22 Ivinović v Croatia, A. 13006/13 (18 Sept 2014) para 37.

23 ibid, para 46; Sahin v Germany, A. 30943/96 (11 October 2001) para 46ff. cf Sérvulo \& Associados - Sociedade de Advogados, Rl v Portugal, A. 3569/12 and others, (17 September 2015) (the seizure of computer records in the offices of the law firm had been compensated for by procedural safeguards to prevent abuse and arbitrariness and to protect legal professional secrecy).

24 Junta Rectora Del Ertzainen Elkartasuna v Spain, A. 45892/09 (21 April 2015) (ban on strikes by police officers' union within Spain's wide MoA).

${ }^{25}$ A.S. v Switzerland, A. 39350/13 (30 June 2015); A, B and C v Ireland [GC), A. 25579/05, para 241. For criticism of the deference to internal moral views see the partly dissenting opinion of six judges; Krishnan (n 71).

26 Stübing $v$ Germany, A. 43547/08, para 61.

27 Evans v UK [GC], A. 6339/05, para 77, ECHR 2007-I (concerning an ex-partner's consent for the use of frozen embryos); Eweida and Others $v$ UK, A. 48420/10, 59842/10, 51671/10 and 36516/ 10, para 109 (wearing of religious symbols by employees); Bohlen v Germany, A. 53495/09, paras 45-60 (margin of appreciation is particularly wide in the commercial sphere).

28 Axel Springer AGv Germany, A. 39954/08, para 87 (discussing arts 8 and 10 ECHR). 
protection by weighing up the interests at stake in detail and in depth. ${ }^{29}$ The ECtHR may also afford a wider MoA during a particular historical background, such as during a transition to democracy. ${ }^{30}$ However, there will come a point where the transition is considered to have been sufficiently consolidated and the margin will narrow. ${ }^{31}$ The application of the MoA means that some restrictions on rights may vary from one State to another or even from one region to another within the same State, especially a State that has opted for a federal type of political organization. ${ }^{32}$ In such cases only serious reasons could lead the ECtHR to substitute its own assessment for that of the national and local authorities, which are closer to the realities of their country, for it would thereby lose sight of the subsidiary nature of the Convention system. ${ }^{33}$

If a restriction on fundamental rights applies to a particularly vulnerable group in society, who have suffered considerable discrimination in the past, then the State's MoA is substantially narrower and it must have very weighty reasons for the restrictions in question. This approach has been applied, for example, in the context of those suffering different treatment on the ground of their gender, 34 race, ${ }^{35}$ sexual orientation ${ }^{36}$ or mentally disability. ${ }^{37}$ The reason for this approach, which questions certain classifications per se, is that such groups were historically subject to prejudice with lasting consequences, resulting in their social exclusion. Such prejudice may entail legislative stereotyping which prohibits the individualized evaluation of their capacities and needs. ${ }^{38}$

It is critical to emphasize that the MoA afforded to States is an instrument of supervision-European supervision goes 'hand in hand' with it. The MoA is not an instrument of surrender or abdication. Even if the applicable MoA is wide, it is not all-embracing. ${ }^{39}$ European supervision is not limited to ascertaining whether the State exercised its discretion reasonably, carefully and in good faith. These elements are necessary but not sufficient. The ECtHR commonly uses the language of whether the State has remained within, or not overstepped, an 'acceptable' MoA. ${ }^{40}$

The ECtHR has to satisfy itself that the standards applied by national authorities were in conformity with the principles embodied in the

29 Fernandez-Martinez v Spain [GC], A. 56030/07, paras 123-153,(12 June 2014); Nicklinson v $U K$, A. 2478/15 (16 July 2015).

30 Rekvényi v Hungary [GC], A. 25390/94, paras 44-50 (decided in May 1999).

31 See Vajnai v Hungary, A. 33629/06, paras 48-58 (decided in July 2008). See JA Sweeney, The European Court of Human Rights in the Post-Cold War Era (Routledge 2013).

32 Mouvement Raëlien Suisse v Switzerland [GC], A. 16354/06, paras 64-65. 33 ibid.

34 Abdulaziz, Cabales and Balkandali v the UK, A. Nos 9214/80; 9473/81; 9474/81, (1985) para 78.

${ }^{35}$ DH and Others $v$ the Czech Republic [GC], A. 57325/00, para 182.

36 EB v France [GC], A. 43546/02, para 94.

37 Alajos Kiss v Hungary, A. 38832/06, (27 March 2008) para 42.

38 ibid; Shtukaturov v Russia, A. 44009/05, para 95.

39 Hirst v UK (No. 2) [GC], A. 74025/01, para 82.

40 Alajos Kiss (n 37); Odievre v France [GC], A. 42326/98 (2003); SHv Austria [GC], A. 57813/ 00; Parrillo v Italy [GC], A. 46470/11 (27 August 2015) para 197. 
substantive ECHR norms and decisions must have been based on an acceptable assessment of the relevant facts. ${ }^{41}$ It is notable that there are many cases in which the ECtHR affords States a wide MoA but then decides that States have not remained within it, usually due to disproportionality ${ }^{42}$ or the lack of a fair balance, and so there is a violation. ${ }^{43}$ Even where the ECtHR is clear that it is an area where States have an MoA, reasonable judges may disagree on whether a fair balance has been struck in an individual case. ${ }^{44}$

\section{B. The Relationship between the MoA and the Standard of Review}

A critical element to appreciate is that the scope of the MoA afforded directly relates to the strictness of review. Broadly speaking, the wider the margin, the less strict the scrutiny ${ }^{45}$ and vice versa. However, this is only a generalization or starting point. In Alajos Kiss v Hungary ${ }^{46}$ the ECtHR accepted participation in public affairs by voting was an area in which, generally, a wide MoA should be granted to the national legislature.$^{47}$ However, the treatment as a single class of those with intellectual or mental disabilities was a questionable classification, and the curtailment of their rights must be subject to strict scrutiny. ${ }^{48}$

The MoA is likely to be wide, and consequently the standard of review less strict, where economic or social policy issues are involved. ${ }^{49}$ So too with respect to environmental issues. ${ }^{50}$ Where there is a wide MoA the ECtHR sometimes adopts a practice of upholding the State's conduct unless the national court has

41 Rekvényi v Hungary [GC], A. 25390/94, para 44.

42 See $A$ and Others $v$ UK, [GC] A. 3455/05, (n 8); P Popelier and C Van De Heyning, 'Procedural Rationality: Giving Teeth to the Proportionality Analysis' (2013) 9 EuConst 30; T Endicott, 'Proportionality and Incommensurability' in G Huscroft et al. (eds), Proportionality and the Rule of Law: Rights, Justification, Reasoning (CUP 2014) 311.

43 See the cases cited by Kratochvíl (n 13) 337-40.

44 See the 4-3 judgment in Jeunesse v Netherlands A. 12738/10, (3 October 2014). The dissenting judges, Villiger, Mahoney and Silvis, considered that the ECtHR could be seen to be acting as a first-instance immigration court, in disregard of the principle of subsidiarity. The MoA, which was wide in such circumstances, had undergone a 'hot wash'. Similarly the 4:3 judgment in Sõro v Estonia, A. 22588/08 (3 September 2015) in which the dissenters criticized the majority for failing to respect subsidiarity and the margin of appreciation.

45 See Obukhova v Russia, A. 34737/03 (8 January 2009).

46 A. 38832/06, (20 May 2010). 47 ibid, para $41 . \quad 48$ ibid, para 44.

49 Stec and Others $v$ UK [GC], A.65731/01, para 66 (differential retirement ages based on gender). This will usually be the case in the context of art 1 of Protocol 1; Gogitidze v Georgia, A. 36862/05 (12 May 2015). A very wide margin of appreciation was afforded in the in the context of austerity measures, given the unprecedented nature of the economic crisis faced by defendant States, see Koufaki and Adedy v Greece, App Nos 57665/12 and 57657/12, (7 May 2013); Rico v Portugal, A. 13341/14 (24 September 2015). cf the European Committee of Social Rights has strongly asserted States' ongoing obligation to ensure European Social Charter rights in times of crisis; see GENOPDEI/ADEDY v Greece, Complaint No 66/2011, (23 May 2012), IKA-ETAM v Greece, Complaint No 76/2012, decision of December 7, 2012. See generally A Nolan, 'Not Fit for Purpose? Human Rights in Times of Financial and Economic Crisis' (2015) EHRLR 360.

${ }^{50}$ See Powell and Rayner v UK, A. 9310/81 (1990). See also C Hilson, 'The Margin of Appreciation, Domestic Irregularity and Domestic Court Rulings in ECHR Environmental Jurisprudence: Global Legal Pluralism in Action' (2013) 2 Global Constitutionalism 262. 
misinterpreted or misapplied the relevant article of the ECHR or the ECtHR's jurisprudence or had reached a conclusion that was 'manifestly unreasonable' 51 or 'devoid of reasonable foundation'. ${ }^{52}$ Where there is a narrow or limited MoA the burden will be on the State to produce compelling and very weighty reasons to justify the interference. ${ }^{53}$ In such cases there may effectively be a 'presumption of a violation of the Convention'. ${ }^{54}$

\section{Blanket or Indiscriminate Rules}

As the ECHR system has matured States are usually able to comply with requirements that limitations be prescribed by law and have a legitimate aim. Thus it is the ECtHR's analysis of the proportionality of the measures at issue that is often critical. ${ }^{55}$ In a number of the cases the central problem for the ECtHR was that the particular rule was considered to be of a blanket and indiscriminate nature. Examples include Hirst (No 2) vUK (prisoner voting), ${ }^{56} S$ and Marper $v U K^{57}$ (retention of DNA samples and fingerprints in the absence of a criminal conviction) and in Alajos Kiss ${ }^{58}$ (absolute bar on voting by any person under partial guardianship). However, in other situations the ECtHR has accepted that a blanket or indiscriminate rule can be consistent with the ECHR standards. ${ }^{59}$ Even when violations are found, it can be argued that the MoA continues to have a significant influence because the ECtHR leaves considerable discretion to States to devise proportionate schemes in response. ${ }^{60}$ Apart from pilot cases dealing with structural issues, a small number of cases where it considers there would only be one effective remedy, and an increasing number of cases in which the judgment of the ECtHR also seeks to provide assistance-so-called 'judgments with indication of interest for execution (under article 46)', it normally makes no attempt to devise a legislative scheme to remedy the problem. ${ }^{61}$

51 See $A$ and Others $v U K$ [GC], 3455/05, para 174; Benet Czech, spol. s.r.o. v Czech Republic, A. $31555 / 05$, para 40. Members of the UK Supreme Court have differed on whether a stricter test should be applied in different contexts; see $R$ (Tigere) $v$ Secretary of State for Business, Innovation and Skills [2015] UKSC 57.

52 See National and Provincial Building Society and Others $v$ UK, A. 21319/93, para 80.

53 See United Communist Party of Turkey and Others v Turkey, A. 19392/92, para 46; Andrejeva v Latvia [GC], A. 55707/00, para 87.

55 See Legg (n 1) 177-99.

57 [GC], A. 30562/04 and 30566/04 (4 December 2008).

54 Kratochvíl (n 13) 351.

59 See Animal Defenders International v UK [GC], A. 48876/08 (2013) (though the majority was only 9:8). The result may turn on whether the ECtHR considers the relevant provision to be a 'general measure' or a 'blanket ban'. The more convincing the general justifications for the general measures, the less importance the Court will attach to its impact in a particular case. See T Lewis, 'Animal Defenders International v United Kingdom: Sensible Dialogue or a Bad Case of Strasbourg Jitters?' (2014) 77 MLR 460.

${ }^{60}$ See Scoppola v Italy (No. 3), ECtHR [GC], A. 126/2005, paras 93-110.

61 See D Harris et al., Law of the ECHR (3rd edn, OUP 2014) 162-5. Alternatively this remedial aspect could be considered as an aspect of the subsidiary nature of the ECHR system. 
III. THE ROLE OF CONSENSUS IN DETERMINING THE MARGIN OF APPRECIATION

In determining the MoA the ECtHR may, if appropriate, have regard to any consensus and common values emerging from the State practices of the parties to the ECHR. ${ }^{62}$ It makes increasing use of the comparative method ${ }^{63}$ to indicate the degree of any European consensus on a particular issue. ${ }^{64}$ Normally a strong consensus will narrow the MoA and vice versa. ${ }^{65}$ In Schalk and Kopf $v$ Austria ${ }^{66}$ the ECtHR relied on the idea of the MoA and the absence of consensus to deny the existence of an ECHR right to same-sex marriage. ${ }^{67} \mathrm{~A}$ former President of the ECtHR has explained that the ECtHR looked for consensus before it narrowed the margin. He saw this as a safeguard 'to prevent any rapid and arbitrary development of the Convention rights' ${ }^{68}$ and to ensure that 'legal developments keep pace with, but do not leap ahead of, societal changes within Europe'. ${ }^{69}$

Consensus is significant in terms of weighting but it is not necessarily decisive or determinative. ${ }^{70}$ Even a strong consensus amongst a substantial majority of States may not decisively narrow the broad MoA of the State if the broader context of the issue remains one where there is no European consensus $^{71}$ or where 'special historical or political considerations exist which render a more restrictive practice necessary'. ${ }^{72}$ Where there is no consensus within between States, either as to the relative importance of the interest at stake or as to the best means of protecting it, particularly where the case raises sensitive social, moral or ethical issues, the MoA will

62 Bayatyan v Armenia [GC], A. 23459/03, para 122, ECHR 2011 (conscientious objection to military service); K Dzehtsiarou, European Consensus and the Legitimacy of the European Court of Human Rights (CUP 2015); Legg (n 1) 103-44.

${ }^{63}$ See eg Stübing $v$ Germany, A. 43547/08, paras 28-30 (criminalization of consensual sexual acts between adult siblings). See JA Roffee, 'No Consensus on Incest: Criminalization and Compatibility with the ECHR' (2014) 14 HRLR 541. The Court now has a research department to undertake comparative analysis. See K Dzehtsiarou and V Lukashevich, 'Informed DecisionMaking: The Comparative Endeavours of the Strasbourg Court' (2012) NQHR 272. In October 2015 the Court launched a network to exchange information with national superior courts.

64 See Discussion Paper, 'The Role of Consensus in the System of the ECHR' in Dialogue between Judges, (Strasbourg, ECtHR, 2008) available at <http://www.echr.coe.int/Documents/ Dialogue_2008_ENG.pdf> 11-18.

${ }^{65}$ Stübing v Germany, A. 43547/08, paras 58-61; A, B and C v Ireland [GC], A.25579/05, (2011) 53 EHRR 13, paras 229-241. See K Dzehtsiarou, 'Does Consensus Matter? Legitimacy of European Consensus in the Case Law of the European Court of Human Rights' (2011) Public Law 534; Spielmann (n 1) (updated text) 18-25.

66 A. 30141/04 (24 June 2010). For a critique see F Hamilton, 'Why the Margin of Appreciation Is Not the Answer to the Gay Marriage Debate' (2013) EHRLR 47.

67 A. 30141/04, paras 61-62.

68 See N Bratza, Evidence to UK Joint Committee on Human Rights, 13 March 2012, HC 873iii, Q 140 .

69 Bratza (n 14) 124.

70 Hirst v UK (No. 2) [GC], A. 74025/01, para 81; Khoroshenko v Russia [GC], A. 41418/04 (30 June 2015).

71 This was so in $A, B$ and $C$ v Ireland [GC] (n 19), as there remained no European consensus on the scientific and legal definition of the beginning of life, para 237. See S Krishnan, 'What's the Consensus: The Grand Chamber's decision on abortion in A, B and C v Ireland' (2011) EHRLR 200.

72 Republican Party of Russia v Russia, A. 12976/07, para 126. 
be wider. ${ }^{73}$ Alongside the absence of consensus, a number of other factors may point to States having a wider MoA in regulating particular issues. ${ }^{74}$

If an emerging consensus is not based on settled and long-standing principles established in the law of the Member States but rather reflects a stage of development within a particularly dynamic field of law, this will not decisively narrow the MoA. ${ }^{75}$ An important aspect of looking for the consensus is that the jurisprudence on particular controversial issues may take significant periods of time to be established. That gives States time to reflect on comparative social, economic and scientific developments both within and across States. For example, the ECtHR's jurisprudence on transsexuals changed significantly but over a 16 -year period. ${ }^{76} \mathrm{In}$ fact in that particular instance the European consensus had not changed much in that period but the ECtHR considered that there was a 'clear and uncontested evidence' of a 'continuing international trend' in favour of increased social acceptance of transsexuals and of legal recognition of the new sexual identity of post-operative transsexuals. The evidence cited came from Singapore, Canada, South Africa, Israel, Australia, New Zealand and states within the US. ${ }^{77}$ In Oliari and Others $v$ Italy ${ }^{78}$ in 2015 only a thin majority of CoE States (24 out of 47) had already legislated in favour of such recognition of same-sex relationships but the ECtHR referred to rapid development that could be identified globally, with particular reference to countries in the Americas and Australasia. The ECtHR attached some importance to the 'continuing international movement towards legal recognition'. ${ }^{79}$

Generally the working assumption of the ECtHR has been that human rights standards incrementally and progressively increase, ${ }^{80}$ and so the MoA only

${ }^{73}$ SHv Austria (n 40) (concerning the use donated sperm or ova for in vitro fertilization ('IVF'); Hämäläinen v Finland [GC], A.37359/09, 16 July 2014 (concerning a requirement of change of marital status for a transsexual to be recognized as a woman); Parrillo v Italy [GC], A. 46470/11 (27 August 2015) para 180 (broad margin of discretion concerning restrictive legislation on the destruction of human embryos, having regard, inter alia, to the ethical and moral questions inherent in the concept of the beginning of human life and the plurality of existing views on the subject among the different member States); Manole v Romania, A. 46551/06 (16 June 2015).

${ }_{74}$ See Dubská and Krejzová v the Czech Republic A. 28859/11 and 28473/12 (11 December 2014) (no European consensus on whether or not to allow home births. The matter required an assessment by the national authorities of expert and scientific data and involved general social and economic policy considerations of the State, including the allocation of financial resources to set up an adequate emergency system).

${ }_{75}$ S.H. $v$ Austria $[\mathrm{GC}],(\mathrm{n} 40)$ para 96 . The minority disagreed with this additional reference step 'of conferring a new dimension on the European consensus and applying a particularly low threshold to it, thus potentially extending the States' margin of appreciation beyond limits'.

${ }_{77}$ From Rees v UK, A. 9532/81 (1986) to Christine Goodwin v UK, A. $28957 / 95$ (2002).

77 See R Sandland, 'Crossing and Not Crossing: Gender, Sexuality and Melancholy in the European Court of Human Rights' (2003) 11 Feminist Legal Studies 191.

${ }^{78}$ A. 18766/11 and 36030/11 (21 July 2015). The three concurring judges found a violation on the basis of different, narrower reasoning that was not related to consensus or international trends.

79 ibid, para 179 .

${ }^{80}$ See Demir and Baykara v Turkey, No 34503/97, para 146; Vereinigung Bildender Künstler v Austria, A. 68354/01 (on satire as form of artistic expression and social comment). 
tends to narrow over time. Thus consensus is normally relied upon to expand the scope of rights and restrict the scope of limitations. However, legal and social experimentation is possible within limits. ${ }^{81}$ It is clear that it is open to States to impose new restrictions on rights and these may fall within the MoA even if other States have not imposed them. ${ }^{82}$ A striking illustration is the ban on the wearing in public places of clothing that is designed to conceal the face (the socalled Burqa ban). ${ }^{83}$ Of the 47 Member States of the Council of Europe, only France and Belgium had actually imposed such bans. Nonetheless, in $S A S v$ France $^{84}$ in 2014 the ECtHR considered that there was no European consensus as to whether or not there should be a blanket ban on the wearing of the full-face veil in public places. ${ }^{85}$ The ECtHR held that having regard in particular to the breadth of the MoA accorded to France, the ban could be regarded as proportionate to the aim pursued, namely the preservation of the conditions of 'living together' as an element of the 'protection of the rights and freedoms of others' ${ }^{86}$

There are two further factors in support of a consensus analysis. The first is an instrumental one. The ECHR is posited on the idea of shared cultural values based on a 'common heritage of political traditions, ideals, freedom and the rule of law'. ${ }^{87}$ If the interpretation of the ECHR by the ECtHR enjoys widespread underlying support in other States across the Council of Europe, this obviously makes ultimate acceptance and implementation of the ECtHR's evolutive interpretation by national legislatures, executives and judiciaries significantly more likely. ${ }^{88}$ The search for consensus reflects a judicial philosophy of establishing some basic, if increasingly sophisticated, minimum standards rather than one of unifying or harmonizing standards. ${ }^{89}$

81 It is notable that in S and Marper $v U K$ [GC], A. 30562/04 and 30566/04, 4 December 2008, para 112, the ECtHR considered that 'any State claiming a pioneer role in the development of new technologies bears special responsibility for striking the right balance [between public and private interests] in this regard'.

82 See P Mahoney, 'Marvellous Richness of Diversity or Invidious Cultural Relativism?' (1998) 19 HRLJ 4 (on social experimentation).

83 See A Ferrari and S Pastorellivi (eds), The Burqa Affair across Europe: Between Public and private Space (Ashgate 2013).

${ }^{84}$ [GC], A.43835/11, paras 106-159 (1 July 2014). $\quad 85$ ibid, para 156.

86 ibid, para 157. See J Marshall, 'S.A.S. v France: Burqa Bans and the Control or Empowerment of Identities' (2015) 15(2) HRLR 377; A Steinbach, 'Burqas and Bans: The Wearing of Religious Symbols under the European Convention of Human Rights' (2015) 4(1) CJICL 29.

${ }^{87}$ Fifth preamble paragraph of ECHR. See IR del Moral, 'The Increasingly Marginal Appreciation of the Margin-of-Appreciation Doctrine' (2006) 7 German Law Journal 611.

88 See K Dzehtsiarou, 'European Consensus and the Evolutive Interpretation of the ECHR' (2011) 12(10) German Law Journal 1730, 1745. On implementation and compliance difficulties see B Cali and A Koch, 'Foxes Guarding the Foxes? The Peer Review of the Human Rights Judgments by the Committee of Ministers of the Council of Europe' (2014) 14 HRLR 301; D Hawkins and W Jacoby, 'Partial Compliance: A Comparison of the European and Inter-American Courts for Human Rights' (2011) 6 Journal of International Law and International Relations 35.

89 See Vo v France [GC] A. 53924/00, para 22; C Rozakis, 'Is the Case-Law of the European Court of Human Rights a Procrustean Bed?’ (2009) 2 UCL Human Rights Review 51. 
In short, the search for consensus puts a sensible limit on judicial creativity and judge-made law. ${ }^{90}$ The second is a normative one. Judgments of the ECtHR are technically binding only on the State party concerned. However, in effect the jurisprudence has an erga omnes effect. The ECHR has been incorporated in some manner and form in all 47 States parties to the ECHR and they are urged to take account of the ECHR jurisprudence and to draw the necessary implications with respect to their own laws and practice. ${ }^{91}$ Much of the comparative success of the ECHR ultimately depends on the cooperation of the national courts. The Committee of Ministers of the Council of Europe and the ECtHR increasingly stress that implementing ECtHR's judgments is a shared judicial responsibility. ${ }^{92}$

A detailed analysis of the ECtHR's practice with respect to consensus published in 2013 concluded that, 'consensus analysis is a sound and constructive idea'. ${ }^{93}$ However, even when judges accept the concept of looking for consensus in determining the MoA, there have been cases where have been significant and often very critical dissents on how it should be assessed. In Evans $v U K^{94}$ there was a four-judge dissent describing a decision based on a wide MoA due to the absence of a consensus as simplistic and mechanical. ${ }^{95}$ In Chapman $v U K^{96}$ a seven-judge dissent rejected the majority's assertion that the consensus was not sufficiently concrete and their conclusion that the complexity of the competing interests rendered the Court's role a strictly supervisory one. In $X v$ Austria $^{97}$ there was a strong seven-judge dissent on the basis that, as the States in question were sharply divided, therefore there was no consensus. In Animal Defenders International $v$ $U K^{98}$ there was an eight-judge dissent, essentially differing on the application of what they all agreed was a narrow MoA, regarding restrictions on expression on matters of public interest. The majority and the minority differed in their

${ }^{90}$ See P Mahoney, 'Judicial Activism and Self-Restraint in the European Court of Human Rights: Two Sides of the Same Coin' (1990) 11 HRLJ 57.

${ }_{91}$ See Brighton Declaration (n 4); A Kovler and O Chernishova, 'The June 2013 Resolution 21 of the Russian Supreme Court - A Move Towards Implementation of the Judgments of the ECtHR' (2013) 33 HRLJ 263; P Popelier et al. (eds), Human Rights Protection in the European Legal Order: The Interaction between the European and the National Courts (Intersentia 2011).

${ }_{92}$ See Brussels Declaration of "High-Level Conference on "Implementation of the European Convention on Human Rights, our shared responsibility"' (27 March 2015), available at $<$ http:// justice.belgium.be/fr/binaries/Declaration_EN_tcm421-265137.pdf>.

${ }^{93}$ See L Wildhaber et al., 'No Consensus on Consensus? The Practice of the European Court of Human Rights' 33 (2013) HRLJ 248, 262. Similarly, Kratochvíl (n 13) 357. For the argument that consensus fails to provide epistemic justification for the belief that human rights are universal see E-JK Kim, 'Justifying Human Rights: Does Consensus Matter? (2012) 13 Human Rights Review 261.

94 [GC], A. 6339/05.

95 It also stated that the ECtHR 'should not use the margin of appreciation principle as a merely pragmatic substitute for a thought-out approach to the problem of proper scope of review'.

96 [GC], A. 27238/95.

97 [GC], A. 19010/07, (2013) 57 EHRR 14 (concerning second-parent adoption). A number of considerations relating to comparative and international law led the minority to the conclusion that there had been no violations of art 14 taken in conjunction with art 8 ECHR.

98 [GC], A. 48876/08, (22 April 2013). 
assessment of whether there was a European consensus. In Biao v Denmark ${ }^{99}$ there was a 4:3 decision differing fundamentally on the application of the MoA.

\section{JUSTIFICATIONS FOR THE MARGIN OF APPRECIATION}

There are a number of overlapping and related explanations for the MoA being afforded to States. ${ }^{100}$

\section{A. Subsidiarity}

Some aspects of the MoA reflect foundational design and structural issues. First, under the ECHR system, and as now affirmed in Protocol 15, it is States that have the primary responsibility to secure the rights and freedoms defined in the ECHR and its Protocols. ${ }^{101}$ Protocol 15 refers to this primary responsibility as being, 'in accordance with the principle of subsidiarity'. ${ }^{102}$ For the ECtHR the MoA is a reflection of the 'fundamentally subsidiary role of the Convention mechanism' ${ }^{103}$

\section{B. Institutional Competence and Inter-Institutional Comity}

A related aspect of subsidiarity is that the ECtHR is an 'international Court'. ${ }^{104}$ It is not a national or European Constitutional Court, ${ }^{105}$ - though it may have softer constitutional tendencies, characteristics or elements, ${ }^{106}$ - or a European Supreme Court. ${ }^{107}$ The MoA is, in part, a reflection of the relationship between

99 A. 38590/10 (25 March 2014), (rules concerning family reunification). Referred to the GC.

100 See Legg (n 1) 15-66. 101 See text to (n 6).

102 Subsidiarity is emerging as a more complex principle than simply a device to limit the role and powers of the ECtHR. In particular it is being used to impose more stringent remedial standards on domestic courts under art 13 ECHR; see A Mowbray, 'Subsidiarity and the European Convention on Human Rights' (2015) 15 HRLR 313.

103 S.A.S. v France [GC], A.43835/11, para 129. On the MoA being rooted in subsidiarity see P Carozza, 'Subsidiarity as a Structural Principle of International Human Rights Law' (2003) 97 AJIL 38; P Mahoney, 'Universality versus Subsidiarity in the Strasbourg Case Law on Free Speech' (1997) EHRLR 364.

104 Though see M Ajevski, 'Unstable Identities: The European Court of Human Rights and the Margin of Appreciation' (9 June 2014) available at SSRN: < http://ssrn.com/abstract=2474131> (identity of the ECtHR is unstable because its identity as a constitutional court or an international court is uncertain and this makes doctrines like the MoA even more elusive).

105 See CM Zoethout, 'Margin of Appreciation, Violation and (in)Compatibility: Why the ECtHR Might Consider Using an Alternative Mode of Adjudication' (2014) 20 EPL 309.

106 See L Wildhaber and S Greer, 'Revisiting the Debate about "Constitutionalizing" the ECtHR' (2012) 12 HRLR 655; S Hennette-Vauchez, 'Constitutional v International? When Unified Reformatory Rationales Mismatch the Plural Paths of Legitimacy of ECHR Law' in J Christoffersen and MR Madsen (eds), The European Court of Human Rights between Law and Politics (OUP 2011) 150-7.

107 See E Bates, The Evolution of the European Convention on Human Rights (OUP 2010) 35980; A Stone Sweet, 'The ECHR and National Constitutional Reordering' (2012) 33 CardozoLRev 1859. Nor is the ECtHR a fourth instance appeal court though it has been criticized for acting like 
an international court and national democratic systems, ${ }^{108}$ including both their legislatures and their courts. ${ }^{109} \mathrm{It}$ is arguable that a concept like the MoA is necessary to make the interference by an international court with the sovereignty of democratic States tolerable and politically acceptable. ${ }^{110}$ The language of deference is sometimes used to describe the operation of the MoA but this carries misleading connotations of servility. It is submitted that institutional competence, ${ }^{111}$ comparative institutional advantage or judicial self-restraint ${ }^{112}$ are better ways to understand the MoA. The ECtHR has itself described the MoA as a 'tool to define relations between the domestic authorities and the Court'. ${ }^{113}$ The ECtHR asserts that it is highly respectful of national courts, particularly superior courts, which faithfully seek to follow and apply ECHR jurisprudence. In those circumstances, it is respectful in the sense that it will accord their decisions greater deference and will be reluctant to be appearing to micromanage their decisions. ${ }^{114}$ Where a balancing exercise has been undertaken by the national authorities in conformity with the criteria laid down in the ECtHR's case law, the ECtHR requires strong reasons to substitute its view for that of the domestic courts. ${ }^{115}$ Equally when such a balancing exercise has not been conducted then less strong reasons will be needed. The choice of undertaking such balancing is obviously one that national authorities must make for themselves. However, they cannot complain of discriminatory treatment by the ECtHR if they do not seek to follow the ECtHR's jurisprudence. ${ }^{116}$

Of course, tensions in the relationship between superior national courts and the ECtHR are at their greatest when they adopt diametrically opposed interpretations. However, these are relatively few and far between and both sides appear to view the process as a dialogue to be managed rather than a supremacy context. ${ }^{117}$

one, see R Goss, Fair Trial Rights: Article 6 of the European Convention on Human Rights (Hart 2014) 35-64.

${ }_{108}$ See G Letsas, A Theory of Interpretation of the ECHR (OUP 2010) 90-2; Shany (n 3); Legg (n 1) 691-2.

109 See G Neuman, 'Human Rights and Constitutional Rights: Harmony and Dissonance' (2003) 55 StanLRev 1863.

${ }^{110}$ See Mahoney (n 82); E Bates, 'British Sovereignty and the European Court of Human Rights' (2012) 128 LQR 382.

${ }^{111}$ See Lady Arden, 'Peaceful or Problematic? The Relationship between National Supreme Courts and Supranational Courts in Europe' (2010) 29 YEL 3.

${ }_{112}$ See J King, 'Institutional Approaches to Judicial Restraint' (2008) 28 OJLS 409.

113 A and Others $v U K[\mathrm{GC}]$, A. 3455/05, para 184.

114 See N Bratza, 'The Relationship between the UK Courts and Strasbourg' (2011) EHRLR 505, 507, giving examples.

${ }_{115}$ See Axel Springer AG v Germany, A. 39954/08, para 88; Lillo-Stenberg and Sather $v$ Norway, A. 13258/09, para 44; Aksu v Turkey [GC], A. 4149/04 and 41029/04.

116 For a striking case where the ECtHR found that Ukrainian Supreme Court had made a distorted presentation of its findings in a 2007 judgment, see Bochan v Ukraine (No. 2), A. 22251/08), paras 63-65 (5 February 2015).

${ }_{117}$ See Bratza (n 114); Costa (n 141); Mahoney (n 171); Horncastle v UK, A. 4184/10 (16 December 2014). 


\section{Democratic Societies and Democratic Legitimacy}

'Democracy' is the key context or framework within which arguments and reasons have to be articulated within the ECHR system. ${ }^{118}$ The ECtHR has repeatedly explained that pluralism, tolerance and broadmindedness are hallmarks of a 'democratic society'. ${ }^{119}$ Pluralism and democracy must also be based on dialogue and a spirit of compromise necessarily entailing various concessions on the part of individuals or groups of individuals which are justified in order to maintain and promote the ideals and values of a democratic society. ${ }^{120}$ This constant search for a balance between the fundamental rights of each individual is regarded by the ECtHR as the foundation of a democratic society. ${ }^{121}$

Thus, from the ECtHR's perspective, the MoA is a reflection of comparative institutional competence and the contributions from all levels of legislative and judicial bodies can operate within the MoA. Democratic and political legitimacy, even if broadly understood, ${ }^{122}$ push the ECtHR towards respecting the decision of national legislatures, executives and courts. As noted, the MoA is commonly invoked in situations in which there is normative flexibility in the relationship between individual freedoms and collective or societal rights and interests. ${ }^{123}$ As expressed in the Handyside case, the authorities' 'direct and continuous contact with the vital forces of their countries' place them in a better position than the international judge to give an opinion on the exact content of the requirements of permissible limitations and to make the initial assessment of the reality of the pressing social need implied by the notion of 'necessity' in this context of the measures taken to meet such requirements. ${ }^{124}$ In matters of general policy, on which opinions within a democratic society may reasonably differ widely, the ECtHR considers that the role of the domestic policy-maker should be given special weight. ${ }^{125}$ In such circumstances, the ECtHR has a 'duty to exercise a degree of restraint in its review of Convention compliance, since such review will lead it to assess a balance that has been struck by means of a democratic process within the society in question'. ${ }^{126}$ For such respect for national

\footnotetext{
118 Pretty $v$ the United Kingdom [GC], A. 2346/02, (2002) 35 EHRR 1, para 68; A Mowbray, 'Contemporary Aspects of the Promotion of Democracy by the ECtHR' (2014) 20 EPL 469; Mahoney (n 82). See also J Vidmar, 'Judicial Interpretations of Democracy in Human Rights Treaties' (2014) 3 CJICL 532. 119 Şahin v Turkey [GC], A. 30943/96, para 108. 120 ibid.

122 See C A Thomas, 'The Uses and Abuses of Legitimacy in International Law' (2014) OJLS 729.

123 See Letsas (n 108) 84-90 who describes this as the substantive use of the MoA.

124 Handyside (n 12) para 48 (emphasis added).

125 Maurice v France [GC], A. 11810/03, para 117. A common situation of such differing opinions faced by the ECtHR has concerned the relationship between the State and religions, see Şahin v Turkey [GC], para 109.

126 S.A.S. v France [GC], A.43835/11, para 154. cf in Redfearn v UK, A. 47335/06, the dissenting judges considered that, "it was pre-eminently for Parliament to decide what areas require special
} 
decisions to be overborne there needs to be powerful considerations and reasoning based on the core moral principles or values of the human rights concerned. ${ }^{127}$

Thus national authorities are viewed as having stronger, and sometimes more direct, democratic legitimacy and being, in principle, better placed than an international court to evaluate local needs and conditions. ${ }^{128}$ However, the quality of the parliamentary and judicial review of the necessity of the measure in the respondent State is of particular importance to the operation and extent of the relevant MoA. ${ }^{129}$ Quality in this context is probably best understood as meaning substantive and credible discussion of the human rights issues rather than as having to achieve a particular qualitative standard. ${ }^{130}$ In Animal Defenders International $v U K^{131}$ the ECtHR attached considerable weight to exacting and pertinent reviews, by both parliamentary and judicial bodies, of the complex regulatory regime governing political broadcasting in the UK and to their view that the general measure was necessary to prevent the distortion of crucial public interest debates and, thereby, the undermining of the democratic process. ${ }^{132}$ By contrast in Alajos Kiss $v$ Hungary ${ }^{133}$ the ECtHR observed that was no evidence that the Hungarian legislature has ever sought to weigh the competing interests or to assess the proportionality of the relevant restrictions on voting by persons under partial guardianship. Similarly in Dickson $v U K^{134}$ there was no evidence that when fixing the Policy on requests for artificial insemination by prisoners the Secretary of State had sought to weigh the relevant competing individual and public interests or assess the proportionality of the restriction. Further, since the Policy was not embodied in primary legislation, the various competing interests were never weighed, nor issues of proportionality ever assessed, by Parliament.

States will naturally be supportive of the concept of an MoA because it gives them more room for manoeuvre. That is, it affords them more scope for them to take decisions and for those decisions to be judged to be consistent with the

protection in the field of employment and the consequent scope of any exception created to the general rule', para 4.

127 For example, Othman (Abu Qatada) v UK, A. 8139/09, Merits, (2012) 55 EHRR 1, paras 266-267 concerned the approach to an issue of principle concerning a real risk of an extraterritorial violation of the right to a fair trial. See C Michaelsen, 'The Renaissance of NonRefoulement? The Othman (Abu Qatada) Decision of the ECtHR' (2012) 61 ICLQ 750.

128 Greens and MT v UK, A. 60041/08, Merits, (2011) 53 EHRR 21, para 113.

129 Animal Defenders International v UK [GC], A. $48876 / 08$ (2013), para 116; Schindler v United Kingdom, A. 19840/09. See L Lazarus and N Simonsen, 'Judicial Review and Parliamentary Debate' in Hunt et al. (n 139) 385.

${ }^{130}$ cf Animal Defenders International v UK (n 98); Alajos Kiss (n 37); Dickson v UK, [GC] A. 44362/04, para 83 (4 December 2007). In (HS2 Action Alliance Ltd) v The Secretary of State for Transport [2014] UKSC 3 the UK Supreme Court indicated that assessing parliamentary debates would raise constitutional issues in the light of art 9 of the Bill of Rights (1689), see paras 78-79, 200-211. See A Kavanagh, 'Proportionality and Parliamentary Debates: Exploring Some Forbidden Territory’ (2014) 34 OJLS 443.

132 ibid, para 116. ${ }^{133}$ See (n 37) para 41. ${ }^{134}$ A. 44362/04, [GC], para 83 (4 December 2007). 
ECHR. For example, the argument coming from the UK has been that the MoA is either not being applied, is being applied too narrowly, ${ }^{135}$ or is being applied inconsistently. ${ }^{136}$ The ECtHR's approach to the MoA has been the focus of increasing criticism from the UK government in particular. The terms of that critique were partially reflected in the 'Brighton Declaration' and in Protocol 15 ECHR. ${ }^{137}$

The democratic legitimacy argument can only be pushed so far though. ${ }^{138}$ Obviously, as an international court, the ECtHR does not have the same kind of democratic legitimacy that national Parliaments, ${ }^{139}$ national governments and national courts do. ${ }^{140}$ However, it is based on a Treaty that 47 States have consented to and that the Treaty clearly provides for the binding legal status of the ECtHR's judgments. ${ }^{141}$ There is also a limited degree of democratic legitimacy stemming from the election of judges by the Parliamentary Assembly of the Council of Europe. ${ }^{142}$ Moreover, history demonstrates that European democracies have been responsible for significant human rights abuses, including those against minorities such as the Roma. ${ }^{143}$

\section{European Human Rights Standards-Minimal, Uniform or Harmonized}

If the ECtHR is perceived as an 'international Court', rather than a European Constitutional or European Supreme Court, then affording States an MoA is consistent with the idea that the ECtHR's function is not to decree uniformity wherever there are national differences, but to ensure that minimum,

135 See Lord Neuberger, 'The Incoming Tide: The Civil Law, The Common Law, Referees and Advocates' available at < http://webarchive.nationalarchives.gov.uk/20131202164909/http:// judiciary.gov.uk/Resources/JCO/Documents/Speeches/mr-euro-circuit-lecture-june-2010.pdf>; Baroness Hale, 'Common law and Convention Law: the Limits to Interpretation' (2011) EHRLR 534, 542-3 (the evolutive approach to interpreting the Convention tends to lead to a narrowing of the margin of appreciation).

136 See Lord Dyson, 'What Is Wrong with Human Rights?' (2011), Lecture at Hertfordshire University, available at <https:/www.supremecourt.uk/docs/speech_111103.pdf>; Arden LJ (n 111); Kratochvíl (n 13). $\quad 137$ See (n 4).

138 See R Bellamy, 'The Democratic Legitimacy of International Human Rights Conventions: Political Constitutionalism and the European Convention on Human Rights' (2014) 25 EJIL 1019; A von Standen, 'Democratic Legitimacy of Judicial Review beyond the State: Normative Subsidiarity and Judicial Standards of Review’ (2012) ICON 1023.

139 See M Hunt et al., Parliaments and Human Rights (Bloomsbury 2015).

140 See Lord Hoffmann, 'The Universality of Human Rights' (2009) 125 LQR 416; J Sumption, 'The Limits of Law', 27th Sultan Azlan Shah Lecture (20 November 2013) available at <https:// www.supremecourt.uk/docs/speech-131120.pdf>. For a reply to Hoffmann see R Spano, 'Universality or Diversity of Human Rights? Strasbourg in the Age of Subsidiarity' (2014) 14 HRLR 487.

${ }^{141}$ See JP Costa, On the Legitimacy of the European Court of Human Rights' Judgments, (2011) 7 EuConst 173; A Follesdal, 'Much Ado about Nothing? International Judicial Review of Human Rights in Well Functioning Democracies' in A Follesdal, J Schaffer and G Ulfstein (eds), The Legitimacy of International Human Rights Regimes (CUP 2013) 272.

142 See Harris et al. (n 61) 107-9.

143 See DH and Others $v$ Czech Republic, A. 57325/00, para 182. 
fundamental values are respected. ${ }^{144}$ A previous President of the ECtHR has commented that the MoA, 'is a clear expression of the fact that the Convention does not command or even aspire to strict uniformity throughout Europe in the protection of human rights ... The states parties to the Convention are required to secure all Convention rights within their domestic systems, but this does not imply wholesale standardisation of national institutions, procedures and practices. ${ }^{145}$

It is also critically important to understand that the MoA is used by the ECtHR to determine whether or not it considers that there is a violation of the ECHR. That the ECtHR has considered that a particular issue falls within the MoA does not preclude the national authorities, legislative, executive or judicial, from considering that the ECHR should be interpreted at a level above the ECtHR's minimum. However, it must be acknowledged that a finding of no violation based on the MoA may lead to a levelling down of national protections. ${ }^{146}$

\section{CRITIQUES OF THE MARGIN OF APPRECIATION}

The MoA has its critics inside the ECtHR. ${ }^{147}$ Judge De Meyer, famously described references to the MoA as being 'unnecessary circumlocutions' which 'implied relativism' and were 'as wrong in principle as it is pointless in practice'. ${ }^{148}$ There have also been strong academic criticisms of the MoA. ${ }^{149}$ There are critics of the concept's existence and of its use by the

144 See Mahoney (n 103) 369. On comparable issues in an EU context see J Gerards, 'Pluralism, Deference and the Margin of Appreciation Doctrine' (2011) 17 ELJ 80; M Fischera and E Herlin-Karnell, 'The Margin of Appreciation Test and Balancing in the Areas of Freedom, Security and Justice' (2014) 19 EPL 759; Devigne v Commune de Lesparrer-Medoc, CJEU [GC] (6 October 2015).

145 Costa (n 141) 180 (emphases in original). Within the context of fundamental rights jurisprudence the CJEU has effectively recognized that States have an MoA, see N Nic Shuibhne, 'Margins of Appreciation: National Values, Fundamental Rights and the EC Free Movement Law' (2009) ELR 230; Omega Spielhallen- und Automatenaufstellungs-GmbH v Bundesstadt Bonn (C-36/02) [2004] E.C.R. I-9609; [2005] 1 CMLR 5 (freedom to provide services could be restricted when the State considered them to violate the right to human dignity). On concerns that the Court of Justice's expansion of fundamental rights review of Member States action that goes beyond $\mathrm{EU}$ minimum rules can reduce individual rights protection see $\mathrm{M}$ Bartl and $\mathrm{C}$ Leone, 'Minimum Harmonisation after Alemo-Herron: the Janus Face of EU Fundamental Rights Review' (2015) 11(1) EuConst 140.

146 See E Brems, 'Human Rights: Minimum and Maximum Perspectives' (2009) 9 HRLR 349; P Paczolay, 'Consensus and Discretion: Evolution or Erosion of Human Rights Protection?' in Dialogue between Judges (n 64).

147 See RStJ MacDonald, 'The Margin of Appreciation' in RStJ MacDonald et al. (eds), The European System for the Protection of Human Rights (Nijhoff 1993) 83; Engeland and Hanseid $v$ Norway, A. 34438/04, concurring opinion of Judge Rozakis (concept often used automatically and unnecessarily). $\quad{ }_{148} Z v$ Finland, A. 22009/93, dissenting opinion.

149 See Letsas (n 108); E Benvenisti, 'Margin of Appreciation, Consensus, and Universal Standards' (1999) 31 Journal of International Law and Politics 843; A Lester, 'Universality versus Subsidiarity: A Reply’ (1998) EHRLR 73; Arai-Takahashi (n 1); Kratochvíl (n 13); JL Murray (Chief Justice of Ireland), 'Consensus: Concordance, or Hegemony of the Majority?' in 
ECtHR. The fundamental critique is that the MoA erodes normative standards by encouraging their non-uniform, subjectivist or relativist applications, the consequences of which are inconsistent with the universality of human rights ${ }^{150}$ and the concept of the rule of law. ${ }^{151}$ The lack of clarity inherent in the MoA makes for a lack of predictability in judicial decision-making which is inconsistent with the principle of legal certainty. ${ }^{152}$ The search for consensus is thus contrary to basic rule-of-law requirements because it creates vague standards that defeat predictability. ${ }^{153}$ The search for and identification of consensus risks imposing the majority view on minorities within a State ${ }^{154}$ and on a minority, even a substantial minority, of States. The wide MoA afforded by the ECtHR during emergencies has been criticized. ${ }^{155}$ This was partly based on the view that the ECtHR should act as the ultimate protector of human rights. ${ }^{156}$

There are accompanying methodological criticisms of both the role of consensus on determining the MoA and the widely acknowledged absence of a clear and consistent methodology underlying the search for consensus ${ }^{157}$ which States?, how many?, what practice-legal or social?, for how long?, what of the practice of non-parties to ECHR? ${ }^{158}$ And what weight is given to ratified and unratified treaties inside the Council of Europe and outside of it? ${ }^{159}$ One problematic issue for the future will be whether, if the European Union becomes a party to ECHR, EU rules can be regarded as evidence of consensus? ${ }^{160}$ If so, would this create a presumption of their compliance with the ECHR? There has also been criticism of the formulation of the issue or question to which consensus does or does not attach. The answer can vary depending on the formulation. In Şahin $v$ Turkey ${ }^{161}$ the narrow factual issue was the regulation of religious clothing in a university. There was no uniform European conception of the significance of religion in society or the wearing of religious symbols in educational institutions but there was a virtual consensus on whether adult women in universities can wear religious clothing. The ECtHR

Dialogue between Judges (n 64); G Itzcovich, 'One, None and a Hundred Thousand Margins of Appreciation: The Lautsi Case' (2013) 13 HRLR 287.

150 See E Brems, Human Rights: Universality and Diversity (Kluwer 2001) 357-421; M Ajevski, 'Freedom of Speech as Related to Journalists in the ECtHR, IACtHR and the Human Rights Committee: A Study of Fragmentation' (2014) 34 Nordic Journal of Human Rights 118.

151 See Shany (n 3) 912.

152 See JA Brauch, 'The Dangerous Search for an Elusive Consensus: What the Supreme Court Should Learn from the ECtHR' (2009) 52 HowLJ $277 . \quad 153$ ibid.

154 See Benvenisti (n 149). As noted, the ECtHR is sensitive to the fair and proper treatment of people from minorities and avoiding any abuse of a dominant position; see Şahin v Turkey (n 20).

${ }^{155}$ See O Gross and F Ni Aolain, 'From Discretion to Scrutiny...' (2001) 23 HRQ 625.

156 ibid 641. 157 See Wildhaber et al. (n 93); Ajevski (n 150).

158 See the wider range of practice considered in Christine Goodwin v UK (n 76), Oliari and Others $v$ Italy (n 78).

159 See Demir v Turkey, A. 34503/97.

${ }^{160}$ EU accession is likely to be delayed as a consequence of the CJEU's Opinion 2/13 on the draft agreement on the accession of the European Union to the ECHR, (18 December 2014) [2015] 2 CMLR 21.

161 [GC], A. 30943/96. 
chose the first formulation of the consensus issue. The different outcomes of the Chamber and the Grand Chamber in Lautsi v Italy, concerning the display of crucifixes in classrooms, can also be explained by how the issue was framed. ${ }^{162}$

Others regard the MoA as acceptable in principle and an appropriate concept in the subsidiary context in which it is used, but criticize its use or the approach to determining consensus in particular cases. Lord Hoffmann has supported the recognition of the MoA but was critical that there was no consistency in its application. ${ }^{163}$ For him, the ECtHR had not taken the doctrine of the MoA nearly far enough and had been, 'unable to resist the temptation to aggrandise its jurisdiction and to impose uniform rules on Member States.' 164 This was because the ECtHR considered itself the equivalent of the Supreme Court of the United States, 'laying down a federal law of Europe'. ${ }^{165}$ However, he considered that the ECtHR lacked constitutional legitimacy for such a role. ${ }^{166}$ Lord Sumption has similarly criticized the ECtHR for treating the ECHR 'not just as a safeguard against arbitrary and despotic exercises of state power, but as a template for most aspects of human life'. ${ }^{167}$

Another criticism of some uses of the MoA by the ECtHR is that reference to it is a redundant and unnecessary rhetorical justification or conclusory label for an end result. ${ }^{168}$ This is particularly so where the ECtHR has effectively engaged in its own review of the merits by applying a strict standard of proportionality. If it judges the measures proportionate, it simply adds that the State is within its MoA; if not, it simply adds that it has exceeded its MoA. ${ }^{169}$

It is probably fair to say that, notwithstanding the centrality of the MoA in ECHR jurisprudence, there isn't necessarily a clear consensus amongst the current ECtHR's judges on the MoA. However, the majority of them appear to take the view that if national authorities have fully considered a case by reference to the ECtHR's jurisprudence and come to clear reasoned decisions, then serious reasons would be needed to overturn such decisions. ${ }^{170}$ A minority of judges, while accepting the concept of the MoA as such, appear to take a less deferential approach. It is possible that this is partly out of a fear that they would be abdicating their judicial responsibilities. They see the ECtHR as having ultimate interpretative

162 See D McGoldrick, 'Religion in the European Public Square and in European Public Life Crucifixes in the Classroom?' (2011) 11 HRLR 451; Itzcovich (n 149); M Lugato, 'The "Margin of Appreciation" and Freedom of Religion: Between Treaty Interpretation and Subsidiarity' (2013) 52 Catholic Legal Studies 49.

164 ibid. 165 ibid.

163 Lord Hoffmann (n 140) 423.

167 J Sumption, 'Judicial and Political Decision-Making: The Uncertain Boundary' (2011) 16 JR 301. For a critical reply see S Sedley, 'Judicial Politics' (23 Feb 2012) 34(4) London Review of Books. Lord Sumption has continued to criticize the ECtHR for becoming the "the international flag-bearer for judge-made fundamental law extending well beyond the text which it is charged with applying', 'The Limits of Law' (n 140).

${ }_{168}$ See Kratochvíl (n 13); Letsas (n 108) 86-90. ${ }^{169}$ See Arai-Takahashi (n 1) (2002) 232-5.

170 See Friend and Countryside Alliance and Others v UK, A.16072/06 and 27809/08, para 58; A Bardsen, 'The Norwegian Supreme Court and Strasbourg: The Case of Lillo-Stenberg and Scether $v$ Norway' (2014) German Law Journal 1293. 
responsibility with respect to the ECHR and its role as being to set European human rights standards, not to defer to State's assessment of them. ${ }^{171}$ These judges tend to consider each case afresh and take a stricter approach to assessing the actions of national authorities, particularly in terms of applying the principle of proportionality. The result is a greater tendency towards micromanagement. There is also a fear that reliance on the MoA because of the absence of consensus could unintentionally lower national standards. ${ }^{172}$ This is particularly so with respect to the new States that joined after the end of the Cold War. However, in principle this should not happen as the ECHR itself safeguards existing levels of domestic human rights. ${ }^{173}$

The MoA gives States 'room for manoeuvre' 174 while retaining strong elements of European supervision. It is submitted that the complexity of factors taken account of in ECtHR's methodology in applying the MoA, including the weight given to consensus, leads to reason-based, justificatory arguments. ${ }^{175}$ Most decisions of the ECtHR concern the internal, domestic application of human rights norms to individuals with the territory of the State concerned. There is a strong argument that the decisions adopted by the different levels of democratic processes within that territory should bear significant, but not necessarily decisive, weight. ${ }^{176}$ One may disagree with the reasons and the arguments, their factual or evidential basis or epistemic value, but these are different issues. There is thus a process of reasoning, contestation and evaluation which is engaged in by democratic Parliaments and courts and, to some extent, the people. ${ }^{177}$ Giving a significant but not necessarily determinative weight to the existence or non-existence of a consensus is a sensible and credible tool to ensure that the evolution of the ECtHR's jurisprudence keeps pace with but does not move so far ahead of societal changes within Europe that it creates significant risk of nonimplementation. The MoA can thus be understood as a device which

171 See P Mahoney, 'The Relationship between the Strasbourg Court and the National Courts As Seen from Strasbourg' in Ziegler et al. (eds), The UK and European Human Rights - A Strained Relationship (Hart 2015) 21.

172 See P Paczolay (n 146) with respect to the decision in Rekvenyi v Hungary [GC], A. 2390/94.

173 See art 53 ECHR. See also Kennedy v Charity Commission, UK Supreme Court, [2014] UKSC 20, [2014] 2 WLR 808 (ECHR claim failed but claim sent back to judge to consider a stronger case based on common law).

174 This expression is used in the ECtHR's Press Releases to describe the operation of the MoA; see Junta Rectora v Spain (n 24).

175 See also M Cohen-Eliya and I Porat, 'Proportionality and the Culture of Justification' (2011) 59 AmJCompL 466; Hunt et al. (n 139) 425-583.

176 The argument is obviously weaker when the case concerns that extraterritorial application of the ECHR because there no democratic accountability to the affected persons. See Al-Skeini $v$ UK [GC], A. 55721/07 (7 July 2011); Jaloud v Netherlands, A. 47708/08 (20 November 2014).

See B Petkova, 'The Notion of Consensus as a Route to Democratic Adjudication?' (201112) 14 CYELS 663. 
mediates between the idea of universal human rights and leaving space for reasonable disagreement, legitimate differences, and national or local cultural diversity. ${ }^{178}$

VI. THE NON-USE OF THE MARGIN OF APPRECIATION BY THE HUMAN RIGHTS COMMITTEE

As noted, the ECHR's MoA jurisprudence began in the context of derogations. ${ }^{179}$ The HRC, while acknowledging the sovereign right of a State to declare a state of emergency, has asserted a measure of international supervision over that national determination. ${ }^{180}$ That starting point closely parallels that of the ECtHR. ${ }^{181}$ However, while a wide MoA on both the existence of a state of emergency and the appropriate responses to it is central in ECHR jurisprudence on Article 15 ECHR, ${ }^{182}$ the HRC has maintained that it does not use an MoA approach in assessing derogations. This is so even though express reference to the MoA doctrine was made during drafting of the ICCPR at the UN's Third Committee in 1963. ${ }^{183}$ It is notable that the HRC's General Comment 29 (2001) on States of Emergency ${ }^{184}$ made no reference to any MoA.

Elsewhere in its extensive jurisprudence, apart from one early case in $1982,{ }^{185}$ the HRC has not only studiously avoided the language of the MoA, it has expressly disowned it. ${ }^{186}$ Within the context of Article 27 (minority rights) the HRC has stated that while a State may understandably wish to encourage development or allow economic activity by enterprises,

The scope of its freedom to do so is not to be assessed by reference to a margin of appreciation, but by reference to the obligations it has undertaken in Article 27. ${ }^{187}$

This approach could have been limited to articles which do not have express limitations clauses. However, in the HRC's extensive jurisprudence on rights with express limitations the HRC decides cases with reference to the text of the ICCPR, but never by reference to any concept of an MoA. ${ }^{188}$ It emphasized this point in General Comment 34 on 'Article 19: Freedoms of opinion and expression',

\footnotetext{
178 See DL Donoho, 'Autonomy, Self-Governance, and the Margin of Appreciation: Developing a Jurisprudence of Diversity within Universal Human Rights' (2001) 15 EmoryIntlLRev 391; Bellamy (n 138) 1036.

180 Silva $v$ Uruguay, Cmn No 34/87, para 8.1-8.3; GC 28 and GC 29.

$181 \mathrm{cf} A$ and Others $v U K$, A. 3455/05.

182 See Brannigan and McBride v UK, A. Nos 14553/89, 14554/89, 17 EHRR (1994) 539; Harris et al. (n 61) 823-50.

184 UN Doc CCPR/C/21/Rev1/Add.11 (31 August 2001). $\quad{ }^{185}$ The Hertzberg case (n 275).

186 See PR Ghandhi, The HRC and the Right of Individual Communication (Ashgate 1998) 311-14.

187 Länsman et al. v Finland, Cmn No 511/1992, para 9.4 (emphasis added).

188 See generally S Joseph et al. (eds), The ICCPR - Cases, Materials and Commentary (3rd edn, OUP 2013).
} 
The Committee reserves to itself an assessment of whether, in a given situation, there may have been circumstances which made a restriction of freedom of expression necessary. ${ }^{189}$ In this regard, the Committee recalls that the scope of this freedom is not to be assessed by reference to a 'margin of appreciation'190 and in order for the Committee to carry out this function, a State party, in any given case, must demonstrate in specific fashion the precise nature of the threat to any of the enumerated grounds listed in paragraph 3 that has caused it to restrict freedom of expression. ${ }^{191}$

VII. SIMILARITIES AND DIFFERENCES BETWEEN THE EUROPEAN COURT OF HUMAN RIGHTS (ECHR) AND THE HUMAN RIGHTS COMMITTEE/ ICCPR

This section analyses a series of similarities and differences between the ECtHR/ECHR and the HRC/ICCPR. It considers whether alone or in combination they justify or explain the non-use of the MoA by the HRC. It also examines the absence of consensus analysis by the HRC.

\section{A. Similarities and Differences}

In terms of substantive rights the ICCPR is essentially the equivalent of the ECHR only at the global level. In terms of obligations it is States that have the primary responsibility to secure the rights in the ICCPR. The civil and political rights covered, and the language used, are broadly similar. ${ }^{192}$ The HRC follows many of the interpretative approaches of the ECtHR ${ }^{193}$ - the living instrument approach, ${ }^{194}$ purposive interpretation in accordance with object and purpose, ${ }^{195}$ the autonomous meaning of ICCPR terms, ${ }^{196}$ interpretation to include positive and procedural obligations, ${ }^{197}$ reliance upon international standards in other international instruments, ${ }^{198}$ affording a wide scope to rights and a narrow scope to limitations, ${ }^{199}$ and complementarity with other international law norms. In terms of monitoring systems the right of individual petition under the ECHR has evolved over time to become mandatory. Under the First Optional Protocol to the ICCPR the right of individual petition remains optional (but has been accepted by 115 States parties as of 1 October 2015). The ICCPR also has a mandatory reporting system (as do all the UN Treaty bodies and the European Committee of

\footnotetext{
189 Citing Sohn v Republic of Korea, Cmn No 518/1992. $\quad{ }^{190}$ Citing Länsman (n 187).

191 GC 34, para 16 (emphasis added), citing Sohn (n 189) and Shin v Republic of Korea, Cmn No $926 / 2000$.

${ }^{192}$ On the few differences see M Schmidt, 'The Complementarity of the Covenant and the ECHR' in D Harris and S Joseph (eds), The ICCPR and UK Law (OUP 1995) 629.

193 See GC 31 (2004), The Nature of the General Legal Obligation Imposed on States Parties to the Covenant.

194 See Judge v Canada, Cmn No 829/1998, para 10.3. $\quad{ }^{195}$ GC 31 (n 193) para 17.

196 See Van Duzen v Canada, Cmn No 50/1979, para 10.2. ${ }^{197}$ See GC 31 (n 193) paras 6, 8.

198 See GC 21, para 5; GC 35 (see the various instruments cited in the footnotes).

199 See GC 31 (n 193) para 6; GC 34, on Freedom of Expression in art 19 ICCPR.
} 
Social Rights) and an inter-State complaint mechanism (which has never been invoked). If it did explicitly adopt an MoA approach then it would also have to give effect to it in those contexts. ${ }^{200}$

In terms of institutional competence and legitimacy it is significant that the ECtHR is a judicial institution - an international court. It is not a regional constitutional $^{201}$ or regional supreme court. ${ }^{202}$ The HRC is not a judicial institution and it is not an international Court. At best it is a quasi-judicial international committee of independent experts. Like the ECtHR the HRC does not consider itself as a 'fourth instance' body to which appeals can be directed. ${ }^{203}$ The ICCPR system was thus designed at securing minimum fundamental values. It was not directed towards establishing uniform, harmonized rules.

Like the ECtHR, the HRC has a subsidiary role to that of States. Neither its Final Views under the First Protocol or its Concluding Observations and General Comments under the Article 40 ICCPR reporting process are legally binding. It is even more difficult to say that is the HRC rather than States that should act as the ultimate protector of human rights or have the final word in relation to interpretation. ${ }^{204}$ There is a risk that not affording States an MoA could make interferences by the HRC with sovereignty of States intolerable and politically unacceptable. ${ }^{205}$ Many States within the ICCPR system are now broadly democratic. ${ }^{206}$ Democratic and political legitimacy should push the HRC towards respecting the decisions of and the balances struck by national legislatures, executives and courts. This is so particularly with respect to the range of procedural, positive and remedial obligations that the HRC has interpreted into the ICCPR. Finally, the HRC has never suggested that the ICCPR created some new international legal order with its own constitutional framework and founding principles in the way that the CJEU considers the EU Treaties to have done. ${ }^{207}$

It is submitted that such textual, monitoring and institutional differences as there are seem to be inconsequential in relation to the MoA issue under consideration. None of the differences identified seem to provide any justification for a different approach to the issue of an MoA.

\footnotetext{
200 See GC 31 (n 193) para 11.

$201 \mathrm{cf}$ on the Inter-American Courts perception of itself as a regional constitutional court see Candia (n 304).

202 See M Ajevski, 'Unstable Identities: The European Court of Human Rights and the Margin of Appreciation' (9 June 2014) available at SSRN: $<$ http://ssrn.com/abstract=2474131 $>$ who submitted that the identity of the ECtHR is unstable because its identity as a constitutional court or an international court is uncertain and this makes doctrines like the MoA even more elusive.

203 See Drbal v Czech Republic, Cmn No 498/1992, para 6.3.

204 cf Gross and Ni Aolain (n 155) 169.

206 See Freedom House Survey (n 287).

205 cf Mahoney (n 90).

207 In a striking application of the CJEU's conception of the EU legal order it has held that the draft agreement on EU's accession to the ECHR was incompatible with EU Treaties, see Opinion $2 / 13$ (n 160).
} 


\section{B. The Absence of Consensus Analysis by the HRC}

We have noted the critical importance of the consensus approach under the ECHR. ${ }^{208}$ Such an approach can be sensitive to special historical or political considerations, processes of transition towards democracy, the relative importance of the interest at stake, balancing competing private and public interests, maintaining the core essence of rights, protecting historically vulnerable groups, sensitive moral or ethical issues, complex scientific and technical issues. ${ }^{209}$ The same type of considerations can and should equally apply in the ICCPR system. Alongside the absence of consensus, a number of other factors may point to States having a wider MoA in regulating particular issues. ${ }^{210}$ However, if consensus is significant in terms of weighting in Europe why should it appear to be of no or minimal significance in the ICCPR system?211 Can the proper interpretation of the ICCPR really afford to be, or at least appear to be, so divorced from State practice? The risk for the HRC is that, by undervaluing the consent of the relevant community of States as a factor in the interpretation of a human rights treaty, it will lose the support of the international community of States and thereby damage the effectiveness of the international human rights system. ${ }^{212}$

Moreover, if 'consensus analysis is a sound and constructive idea' 213 in Europe, why is it not in the broader international system? If reference to an MoA is important to prevent any rapid and arbitrary development of ECHR rights, ${ }^{214}$ why is this not also the case with the ICCPR? If the width of the MoA is relevant to the standard of scrutiny under the ECHR, does the ICCPR really only apply a single standard of strict scrutiny in all cases, and if so, is that appropriate? If interpretations by the HRC do not enjoy widespread underlying support doesn't this make acceptance and implementation of their Views much less likely? As is well known many States parties do not implement the HRC's Views under OP1. ${ }^{215}$

\footnotetext{
208 See Section III above.
}

209 SH v Austria (n 40) (concerning the use of donated sperm or ova for in vitro fertilization ('IVF'); Hämäläinen v Finland [GC], A.37359/09, 16 July 2014 (concerning a requirement of change of marital status for a transsexual to be recognized as a woman).

210 See Dubská and Krejzová v the Czech Republic, A. 28859/11 and 28473/12 (11 December 2014).

${ }^{211}$ cf G Neuman, 'Import, Export, and Regional Consent in the Inter-American Court of Human Rights' (2008) 19 EJIL 101. He argued that there was reason for concern that the IACtHR had become too divorced from the consensual aspect of a regional human rights convention in its interpretive practices, and that this departure was not compensated for by compelling normative analysis or strategic institutional design.

${ }_{212}$ On the importance to implementing human rights standards of judicial will, domestic sensitivities, public support (or at least lack of opposition), and political organization, see D Anagnostou, The European Court of Human Rights: Implementing Strasbourg's Judgments on Domestic Policy (Edinburgh University Press 2013).

213 See Wildhaber et al. (n 93).

214 See Bratza (evidence) (n 68).

215 On such implementation difficulties see the section in the HRC's annual reports on 'Followup on individual communications under the Optional Protocol'. 
VIII. COMPLEMENTARY AND CONFLICTING JURISPRUDENCE AS BETWEEN THE ECTHR AND THE HRC

\section{A. Interpretative Similarities: Complementary Jurisprudence}

If essentially the same decision is reached then whether the ECtHR's use of the MoA is rhetorical or the HRC's non-use is rhetorical is academically interesting but ultimately insignificant in terms of substance. It is notable that there have been relatively few instances where the HRC and the ECtHR have clearly differed on their assessments with respect to the interpretation of their respective instruments. In many instances the second decision has referenced the first or clearly been taken with knowledge of the first. ${ }^{216}$ A good example is the cases concerning religious instruction in Norway. The HRC has held that such instruction will not satisfy the tests of neutrality and objectivity required by Article 18 ICCPR if it gives priority to one religion (eg Christianity) over another or if it involves the actual practice of a religion rather than the imparting of information. The instruction of 'Christian Knowledge and Religious and Ethical Education' (CKREE) in Norwegian public schools in 1997 was held to have failed on both these counts In Unn and Leirvåg et al. $v$ Norway, ${ }^{217}$ decided in November 2004, the HRC closely scrutinized the framework and practical implementation of an exemption system and found a breach of Article 18(4) (respect for the liberty of parents and, when applicable, legal guardians to ensure the religious and moral education of their children in conformity with their own convictions). ${ }^{218}$ Despite modifications introduced after the decision of the HRC, in 2007 in Folgero v Norway ${ }^{219}$ the Grand Chamber of the ECtHR found, by nine votes to eight, that there had been a violation of Article 2 of Protocol No. 1 to the ECHR (parents' right to respect for their convictions). The minority of eight found that the arrangements for a partial exemption did not entail an excessive or unreasonable burden for parents who wished to make a request for an exemption, and therefore remained within Norway's MoA. They regarded the scope of the case before the ECtHR as more limited than that reviewed on the merits by the HRC and did not view its conclusions as contradicting those reached by the HRC.

\section{B. Interpretative Differences: Conflicting Jurisprudence}

It is particularly instructive to consider the small number of cases where the HRC has reached a different decision than the ECtHR on the substance of essentially the same issue and consider whether it was the non-use of the MoA that made the difference.

216 See Al-Dulimi and Montana Management Inc. $v$ Switzerland, A. 5809/08, 26 November 2013, paras 58-61 (referred to GC), referring to the HRC's decision in Sayadi and Vinck $v$ Belgium, 1472/2006; Balani v Spain, Cmn No 1021/2001. ${ }^{217}$ Cmn No 1155/2003, para 14.3.

218 ibid, paras 14.4-14.5. 219 A. $15472 / 02$. 


\section{Regulation of religious dress on residence and identity documents}

In 2008 in Mann Singh v France ${ }^{220}$ the ECtHR Court accepted that identity photographs on driving licences which showed MS, a Sikh, bareheaded were needed by the authorities in charge of public safety and law and order, particularly in the context of checks carried out under the road traffic regulations, to enable them to identify the driver and verify that he or she was authorized to drive the vehicle concerned. It stressed that checks of that kind were necessary to ensure public safety within the meaning of Article 9(2) ECHR. It considered that the detailed arrangements for implementing such checks fell within France's MoA, especially since the requirement for persons to remove their turbans for that purpose or for the initial issuance of the licence was a sporadic one. It therefore held that the impugned interference had been justified in principle and was proportionate to the aim pursued. The application was declared manifestly ill-founded without even communicating it to the State and without any more detailed reasoning and analysis. $^{221}$

In two decisions in 2011 and 2013 the HRC took completely the opposite view. Ranjit Singh v France ${ }^{222}$ in 2011 concerned a refusal to renew a residence permit in the absence of an identity photograph showing RS, a Sikh, bareheaded. RS claimed that because he did not have a residence permit, he no longer had access to the public health-care system or to social benefits. RS did not make an application to the ECtHR on the basis that its established jurisprudence was against him. He cited national court decisions and the decision of the ECtHR in Mann Singh v France, considered above, in support of this. There was no dispute that the measure was prescribed by law and had the legitimate aim of ensuring and verifying, for the purposes of public safety and public order, that the person appearing in the photograph on a residence permit was in fact the rightful holder of that document. The HRC asserted that it was for it to determine whether Article 18(3) ICCPR was satisfied. Its task was to decide whether that limitation was necessary and proportionate to the end sought. It unanimously decided that it was not on the basis that,

the State party has not explained why the wearing of a Sikh turban covering the top of the head and a portion of the forehead but leaving the rest of the face clearly visible would make it more difficult to identify the author than if he were to appear bareheaded, since he wears his turban at all times. Nor has the State party explained how, specifically, identity photographs in which people appear bareheaded help to avert the risk of fraud or falsification of residence permits. ${ }^{223}$

220 A. $24479 / 07$ (13 November 2008).

221 In a controversial ruling the HRC has decided that where the ECtHR declared a matter manifestly ill-founded, it had not 'considered' the application and so it could be considered again by the HRC despite a reservation by the State precluding reconsideration. See J Gerards, 'Inadmissibility Decisions of the European Court of Human Rights: A Critique of the Lack of Reasoning' (2014) 14 HRLR $148 .{ }^{222}$ Cmn No 1876/2000. 223 ibid, para 8.3. 
Consequently, France had not demonstrated that the limitation placed on RS was necessary within the meaning of Article 18(3). The HRC also observed that,

even if the obligation to remove the turban for the identity photograph might be described as a one-time requirement, it would potentially interfere with the author's freedom of religion on a continuing basis because he would always appear without his religious head covering in the identity photograph and could therefore be compelled to remove his turban during identity checks. The Committee therefore concludes that the regulation requiring persons to appear bareheaded in the identity photographs used on their residence permits is a limitation that infringes the author's freedom of religion and in this case constitutes a violation of article 18 of the Covenant. ${ }^{224}$

Essentially the same approach was followed in Mann Singh $v$ France, ${ }^{225}$ decided by the HRC in 2013. MS, a Sikh, and the same individual who had earlier brought a case to the ECtHR, ${ }^{226}$ had obtained a series of French passports, for each of which he had been photographed wearing his turban. However, when he sought a renewal in 2005 he was informed that, pursuant to a Decree of 2001, he was obliged to be photographed without the turban. Challenges before the French courts and, as noted, before the ECtHR, failed. Although the factual issue before the HRC was different, France specifically pointed out that MS was effectively asking the HRC to disagree with the French courts and the ECtHR. It pointed to the similarity of wording between Article 9 ECHR and Article 18 ICCPR, the very strong similarity between the cases and the high level of protection of human rights afforded by both the ECtHR and the HRC. France claimed that the requirement was authorized by Article 18(3) as it responded to, 'the need to limit the risk of fraud or falsification of passports and facilitates the identification of the passport holder by the administrative authorities, while the constraints involved are only temporary'. 227

Nonetheless, the HRC asserted that it was for it to determine whether Article 18(3) was satisfied. Again, there was no dispute that the measure was prescribed by law and had the legitimate aim of ensuring and verifying, for the purposes of public safety and public order, that the person appearing in the photograph on a passport was in fact the rightful holder of that document. The HRC's task was to decide whether that limitation was necessary and proportionate to the legitimate aim. It unanimously decided that it was not. The HRC made the same observations on France's explanations and the continuing basis of the interferences as in the Ranjit Singh case. Again, therefore, the HRC concluded that the regulation requiring persons to appear bareheaded in their passport photographs was a disproportionate limitation that infringed the MS's freedom of religion and constituted a violation of Article 18.228

224 ibid.
227 Cmn No 1928/2010, para 9.2.

226 See (n 220).
228 ibid, paras $9.4-9.5$. 
Is it possible to distinguish the cases decided by the ECtHR and the HRC? Inability to travel outside of France because of the absence of a passport (the issue in Mann Singh before the HRC) would have a fundamental effect on freedom of movement. ${ }^{229}$ Inability to obtain a driving licence (the issue in Mann Singh before the ECtHR) was of a lesser order but nonetheless of immense practical significance to the daily lives of individuals. The HRC's decision in Ranjit Singh (concerning a residence permit which was important for lots of practical reasons including access to health care and social benefits) suggests that distinguishing between the cases in this way would not be defensible. If not, then there is just a blatant difference between the jurisprudence of the HRC on one side and the French courts and the ECtHR on the other. The rights and limitations being applied are essentially the same. The narrowest explanation of the difference is that the HRC just reached a different position in terms of a factual assessment of how the restrictions would practically affect identification issues and the continuing nature of the interferences. It considered that the French explanations of the identification difficulties in both cases were unconvincing. Another explanation is that the HRC just took a stricter view on the proportionality of the measures. If so, it is disconcerting for States that what one international human rights institution unanimously (7 judges) considers proportionate, another unanimously considers disproportionate. A final explanation for the conflicting jurisprudence is that the ECtHR afforded the State an MoA that the HRC does not and the actual effect is to lower human rights standards as feared by critics of the MoA. Consistent with its established jurisprudence, neither of the HRC's views made any reference to any MoA.

What is unhelpful is that we can only speculate on these possible explanations. Given that France had specifically raised the issue of divergent interpretations, much more by way of explanation and reasoning should be expected from the HRC, in particular in relation to its assessment of proportionality. In particular it might have been thought important to discuss other States' practices. In Mann Singh before the HRC the author claimed, inter alia, that 'most European countries and others such as Australia, Canada, New Zealand and the United States of America, which have the same concerns as France regarding security and fraud, allow religious symbols to be worn on the head in identity photographs. France is the only country of the European Union that requires passport photographs to be bareheaded.' 230 Such a discussion might have suggested that the HRC considered that the ECtHR should have found a violation even on the basis of its own approach to consensus as an aspect of the MoA. ${ }^{231}$ Or at least the

229 See SO Chaib, 'Mann Singh wins turban case in Geneva after losing in Strasbourg', 19 November 2013, available at <http://strasbourgobservers.com/2013/11/19/mann-singh-wins-ingeneva-after-losing-in-strasbourg/>.

${ }^{230}$ Mann Singh v France, para 7.3.

231 See Section III above. 
ECtHR would have been expected to have explained why such a consensus was not regarded as determinative, as in $S A S v$ France. ${ }^{232}$

\section{Regulation of religious dress in schools}

Even more striking is the divergent jurisprudence on the regulation of religious dress in schools. ${ }^{233}$ Ranjit Singh v France ${ }^{234}$ and Jasvir Singh v France ${ }^{235}$ concerned pupils in schools wearing a keski (a small light piece of material of a dark colour, substituting for a turban) while Aktas $v$ France ${ }^{236}$ and three other cases $^{237}$ concerned Muslim pupils wearing a bonnet (substituting a headscarf). The cases challenged a French Law of 15 mars 2004, (loi no 2004-228) entitled 'en application du principe de laïcité, le port de signes ou de tenues manifestant une appartenance religieuse dans les écoles, collèges et lycées publics'. The law prohibited 'le port de signes ou tenues par lesquels les élèves manifestent ostensiblement une appartenance religieuse'. In 2009 the ECtHR declared the claims of all these applicants manifestly ill-founded in similar inadmissibility decisions. The decisions were based on the detailed reasoning used in 2008 judgments of Dogru v France and Kervanci v France ${ }^{238}$ concerning pupils who were prohibited to wear a headscarf during sport education classes. In these cases, the ECtHR referred to earlier judgments in which it held that it was for the national authorities, in the exercise of their MoA, to take great care to ensure that, in keeping with the principle of respect for pluralism and the freedom of others, the manifestation by pupils of their religious beliefs on school premises did not take on the nature of an ostentatious act that would constitute a source of pressure and exclusion. In the ECtHR's view, that concern did indeed appear to have been answered by the French secular model. ${ }^{239}$ Having regard to the MoA which must be left to the Member States with regard to the establishment of the delicate relations between the Churches and the State, religious freedom recognized and restricted by the requirements of secularism appeared legitimate in the light of the values underpinning the ECHR. ${ }^{240}$ The conclusion reached by the national authorities that the wearing of a veil, such as the Islamic headscarf, was incompatible with sports classes for reasons of health or safety was not unreasonable. The penalty imposed was merely the consequence of the applicant's refusal to comply with the rules applicable on the school

232 See (n 84).

233 The HRC's decision in Hudoyberganova v Uzbekistan, Cmn No 931/2000, finding a violation with respect to a university student who could not wear an Islamic headscarf could be treated as conflicting with ECtHR jurisprudence but the decision was in substance a default decision in the absence of any justification from the State. See D McGoldrick, Human Rights and Religion: The $\begin{array}{ll}\text { Islamic Headscarf Debate in Europe (Hart 2006) } 225 . & \text { A. 27561/08. }\end{array}$ 235 A. 25463/08. 236 A. 43563/08.

237 Bayrak v France, A. 14308/08, Gamaleddyn v France, A. 18527/08, and Ghazal v France A. $29134 / 08$.

239 Dogru, para 71.

238 A. $31645 / 04$ and $27058 / 05$. 240 ibid, para 72. 
premises - of which she had been properly informed - and not of her religious convictions, as she alleged. ${ }^{241}$ In the five cases in 2009 the ECtHR saw no reason to deviate from this case law even though the scope of the 2004 prohibition legislation was wider than a prohibition on wearing headgear in sport education classes. The fact that the national authorities considered that more 'discrete' headgear such as a keski instead of a turban and a bandana or bonnet instead of a headscarf that the applicants wore still came within the prohibition in the national legislation came within the State's MoA. The reasoning of the national authorities was not unreasonable. ${ }^{242}$

The HRC has taken completely the opposite view to the same issue. ${ }^{243}$ In Bikramjit Singh v France, ${ }^{244}$ decided in 2013, BS had been denied access to his classes at school because of the wearing of a keski, in place of a turban. The decision was based on the 2004 French legislation considered by the ECtHR in Dogru and the other French cases noted above. Initially BS had to sit in the school's canteen to study on his own. After a short period of dialogue between the school authorities and BS's family, the school expelled BS from school since he refused to comply with the school's demand to remove his keski in the school premises. Interestingly both BS and the State made reference to the idea of a State having an MoA. ${ }^{245}$ France cited the case law of the ECtHR, specifically the Dogru and Kervanci cases, which allowed States parties to the ECHR some room for manoeuvre. It submitted that this reflected the ECtHR's intention to take account of choices, particularly constitutional and legislative choices, made by States attached to the principle of secularism, while monitoring observance of the rights and freedoms protected by the ECHR. ${ }^{246}$

Again the HRC asserted that it was responsible for deciding whether any limitation was necessary and proportionate to the end sought, as defined by the State. The HRC recognized that the principle of secularism (laïcité) was itself a means by which a State may seek to protect the religious freedom of all its population, and that the adoption of Act No. 2004-228 responded to actual incidents of interference with the religious freedom of pupils and sometimes even threats to their physical safety. Therefore, it considered that Act No. 2004-228 served purposes related to protecting the rights and freedoms of others, public order and safety. Moreover, the HRC noted that the regulation was adopted in response to certain contemporary incidents. The HRC also noted S's statement, not challenged by the State, that for Sikhs, males, wearing a keski or turban was not simply a religious symbol, but an essential

241 ibid, para 73.

242 See R Negro, 'The Margin of Appreciation Doctrine and the Case-Law of the European Court of Human Rights on the Islamic Veil' (2010) 11 Human Rights Review 531. For the application of the MoA to a wider prohibition on face covering in public see S.A.S. v France [GC], A.43835/11.

243 See SO Chaib, 'Freedom of Religion in Public Schools: Strasbourg Court v. UN Human Rights Committee' 14 Feb 2013, available at <http:/strasbourgobservers.com/2013/02/14/ freedom-of-religion-in-public-schools-strasbourg-court-v-un-human-rights-committee/ $>$.

${ }^{244}$ Cmn No 1852/2008. 245 ibid, para 3.5. 246 ibid, para 5.5. 
component of their identity and a mandatory religious precept. It also noted the State's explanation that the prohibition of wearing religious symbols affected only symbols and clothing which conspicuously display religious affiliation did not extend to discreet religious symbols and the Council of State took decisions in this regard on a case-by-case basis. However, the HRC was of the view that the State had 'not furnished compelling evidence that, by wearing his keski, S would have posed a threat to the rights and freedoms of other pupils or to order at the school'. ${ }^{247}$ It was also of the view that the penalty of the pupil's permanent expulsion from the public school was disproportionate and led to serious effects on the education to which S, like any person of his age, was entitled in the State. ${ }^{248}$ It was not convinced that expulsion was necessary and that the dialogue between the school authorities and the author truly took into consideration his particular interests and circumstances. Moreover, the State imposed this harmful sanction on $\mathrm{S}$, not because his personal conduct created any concrete risk, but solely because of his inclusion in a broad category of persons defined by their religious conduct. ${ }^{249}$ In this regard, the HRC noted the State's assertion that the broad extension of the category of persons forbidden to comply with their religious duties simplified the administration of the restrictive policy. However, in the HRC's view, the State had not shown how the sacrifice of those persons' rights was either necessary or proportionate to the benefits achieved. For all these reasons, the HRC concluded that the expulsion of the author from his lycée was not necessary under Article 18(3), infringed his right to manifest his religion and constituted a violation of Article 18. ${ }^{250}$

Distinguishing the approaches of the ECtHR and the HRC is even more difficult in these cases. They appear manifestly inconsistent on the same issue. Again there is no reference to the MoA by the HRC. One commentator has been supportive of the HRC's approach:

While the ECtHR views the cases merely in light of the interests of the State, the UN Committee balances the arguments of all parties in a more convincing way, taking the fundamental rights of the applicants seriously all the while acknowledging the State's interests. Hence, with this case the UN Committee gives again a clear signal that a general principle such as secularism, however important, cannot blindly trump individuals' rights, such as the right to freedom of religion, without looking at the particularities of the case..$^{251}$

Such an approach places great weight on the individuals' rights against those of the wider community represented by the State. When restrictions are imposed

247 ibid, para 8.7 (emphasis added). $\quad 248$ There is no right to education in the ICCPR.

249 Bikramjit Singh, para 8.7 (emphasis added).

250 ibid. Having ascertained that a violation of art 18 occurred, the HRC did not examine the claim based on a separate violation of the principle of non-discrimination guaranteed by art 26 .

251 See Chaib (n 243). There is also a broader critique that the ECtHR has not been strong enough in its defence of the rights of religious believers. Eweida and Others $v U K$ (n 27), moves the ECtHR's jurisprudence more firmly into the necessity for balancing and away from notions of non-interference. 
on the basis of general principles such as secularism it is impossible for the State to provide compelling evidence that, by wearing his keski, S would have posed a threat to the rights and freedoms of other pupils or to order at the school or that his personal conduct created any concrete risk. ${ }^{252}$ That is too individualistic an approach and would fail in the vast majority of cases. The threat comes not from the single individual but from the combined effect of all the religious individuals concerned. ${ }^{253}$ As the ECtHR has observed, concessions on the part of individuals or groups of individuals can be justified in order to maintain and promote the ideals and values of a democratic society. ${ }^{254}$ Arguing that a general principle such as secularism 'blindly trumps' an individual's rights does not give proper weight and appreciation to a general principle that, as both the ECtHR and HRC have accepted, seeks to protect the religious freedom of all its population. It is submitted that the lack of reasoning and explanation of the HRC do not do justice to this issue. ${ }^{255}$ Again it also puts the State concerned, France, and other States relying on the established jurisprudence of the ECtHR in a very difficult position. If the HRC is clearly aware that it is disagreeing with the established jurisprudence of the ECtHR, or any other regional human rights body, it surely has some responsibility to provide a detailed justification for that. It is notable that France has taken no action to action taken to implement the HRC's recommendations on remedies for the violations it found in Ranjit Singh v France, Mann Singh v France and Bikramjit Singh v France.

The terms of OP1 mean that individuals can go to the HRC after their case has been considered by the ECtHR unless the State has made a reservation to OP1 to preclude this. $^{256}$ One of the consequences of fundamental divergences in interpretation is that individuals may do exactly that. Or they may simply go to the HRC rather than to the ECtHR, even though the result is a non-legally binding view rather than a legally binding judgment. ${ }^{257}$

IX. EXPLANATIONS FOR THE NON-USE OF THE CONCEPT OF THE MARGIN OF APPRECIATION BY THE HUMAN RIGHTS COMMITTEE

There are a range of possible explanations.

\section{A. Protecting the Universality of Human Rights}

The Preambles to both the ICCPR and the ECHR refer back to the Universal Declaration of Human Rights (1948). So the simplest explanation of non-use

\footnotetext{
252 The same was true of the individual in the Şahin $v$ Turkey case (n 20).

253 The same argument would apply mutatis mutandis to the 'living together' basis of S.A.S. $v$ France [GC], A.43835/11. $\quad 254$ Şahin v Turkey (n 20). $\quad{ }^{255}$ See McGoldrick (n 233).

256 See also Gerards (n 221).

257 See E Brems et al., 'Le port de signes religieux dans l'espace public: verité à Strasbourg, erreur à Genève?' Journal des Tribunaux (2012) 602-3.
} 
of the MoA is that it is a threat to the universality of human rights. ${ }^{258}$ As such, the threat should not be supported or encouraged. The risk of expressly acknowledging the existence of an MoA would be that States would inevitably seek support from it to validate a diminishing and variable normative content for international human rights. Admitting an MoA doctrine "might prompt some States to rely on arguments of "cultural relativism", however ill-defined or inappropriate in the circumstances of a given case, or seek to justify serious human rights abuses'. ${ }^{259}$ Whilst the risk is comprehensible the explanation depends on a rather simplistic and unreal conception of universality. ${ }^{260}$ The critical prior question is to determine the scope of the obligations under the substantive ICCPR rights. Although human rights are universal in the sense of imposing some minimum fundamental standards, universalism does not operate by means of uniform, harmonized rules which cannot be varied. ${ }^{261}$ This is true with respect both to the protection of rights and remedies. Once the scope of the obligations has been established then the requirements under Article 2 to respect and ensure ICCPR rights are unqualified and of immediate effect. A failure to comply with this obligation cannot be justified by reference to political, social, cultural, and economic considerations or by traditional, historical, religious or cultural attitudes within the State. ${ }^{262}$

\section{B. Anti-Eurocentrism}

A second explanation of non-use of MoA by HRC lies in the MoA's association with the ECHR system. A number of members of the HRC have also been members of the ECtHR or the European Commission on Human Rights. ${ }^{263}$ Particularly in its first decades the HRC did not want to appear to be Eurocentric in approach. That may have been a sensitive political explanation for the early practice of the HRC but as it matured it had to determine the jurisprudential approach that was appropriate in principle, irrespective of

258 Benvenisti (n 149). J Crawford, 'Preface' to Arai-Takahashi (n 1), suggested that the HRC avoids use of MoA 'apparently on the basis that it is inconsistent with very idea of human rights', at ix.

259 See Schmidt (n 192) 657.

260 See J Donnelly, 'The Relative Universality of Human Rights' (2007) 29 HRQ 281; C Tomuschat, Human Rights: Between Idealism and Realism (3rd edn, OUP 2014) 47-72. L Lazarus, C McCrudden and N Bowles (eds), Reasoning Rights: Comparative Judicial Engagement (Hart 2014). I deliberately leave aside broader critiques of universality and of the Eurocentric history of human rights; see J-M. Barito, 'Decolonial Struggles and Dialogue in the Human Rights Field' in J-M Bareto (ed), Human Rights from a Third-World Perspective (Cambridge Scholars 2013).

261 See P Contreras, 'National Discretion and International Deference in the Restriction of Human Rights: A Comparison between the Jurisprudence of the European and the InterAmerican Court of Human Rights' (2012) 11 Northwestern Journal of International Human Rights Law 28.

262 General Comment 31 (n 209) para 14; General Comment 28, art 3 - The equality of rights between men and women, para $5 . \quad 263$ For example, Opsahl, Ermacora, Vincent-Evans, Palm. 
where it had been used or was associated with. Of the 47 States parties to ECHR, 46 are also parties to the ICCPR (the only exception is Moldova). Many of them have accepted OP1 and argued before the HRC that decisions of the ECtHR or at least its jurisprudential approach, based on an application of the MoA (or a margin of discretion), ${ }^{264}$ should be followed. ${ }^{265}$ For example, in $B W M Z v$ Netherlands ${ }^{266}$ the State submitted observations on admissibility and merits. It recalled the decision of inadmissibility adopted by the ECtHR and asked the HRC, for reasons of legal certainty, to take a similar approach, that was, to declare that the communication was inadmissible or that it did not constitute a violation of the Covenant. Otherwise, the State would be confronted with contradictory rulings by two international supervisory bodies on an identical issue. ${ }^{267}$ In other cases States have argued for an MoA even when there is no equivalent ECHR jurisprudence. ${ }^{268}$ Thus in MBv Czech Republic $^{269}$ the State argued that the legislator possessed an MoA within which it could lay down citizenship requirements on the part of applicants requesting the surrender of property.

So anti-Eurocentrism may be a sensitive political and comparative explanation but it is not a sensible justification. The crucial issue is to determine whether the concept of the MoA is jurisprudentially sound or not. On the basis of the comparisons in Section VII above it is submitted that it is. Not only would it not be Eurocentric to afford an MoA to States parties to the ICCPR, it would rather be a sensitive response to criticisms of the purported universality of international human rights.

\section{Misunderstanding of the $M o A$}

A third possible explanation for non-use of the MoA by the HRC is that there may be a misunderstanding of the MoA and how it operates. If there is an interference with a right but it is justified then there is no violation. ${ }^{270}$ If it is justified only because it is held to fall within the MoA for the State concerned the same analysis applies. That a situation falls within the MoA

264 See Atasoy et al. v Turkey, Cmn Nos 1853/2008 and 1854/2008, para 7.6; Sechremelis v Greece, Cmn No 1507/2006, para 8.2; Albareda et al. v Uruguay, Cmn Nos 1637/2007, 1757/ 2008 and 1765/2008, para 4.2; Brychta v The Czech Republic, Cmn No 1618/2007, para 4.2.

265 See Brandsma v The Netherlands, Cmn No 977/2001, paras 4.2-4.3; Crippa, et al. v France, Cmn No 993-995/2001, para 4.10; Vojnovic v Croatia, Cmn No 1510/2006, para 4.10; Althammer et al. v Austria, Cmn No 803/1998, para 4.6; Qv Denmark, Cmn No. 2001/2010, para 5.4. See also the cases discussed in Section VIIIA below.

${ }^{266}$ Cmn No 1788/2008, para 4.1. The communication was inadmissible for non-exhaustion of domestic remedies or non-substantiation of claims.

267 Some States have avoided this possibility by reservations to prevent reconsideration of cases. See C Phuong, 'The Relationship between the European Court of Human Rights and the Human Rights Committee: Has the "Same Matter" Already Been "Examined"?' (2007) 7 HRLR 385; Gerards (n 221).

268 See Novotny v Czech Republic, Cmn No 1778/2008, para 4.6.

${ }^{269}$ Cmn No 1849/2008, para 4.16. The communication was declared inadmissible because the delay in submission was so unreasonable and excessive as to amount to an abuse of the right of submission.

270 See Eweida and Others $v$ UK (n 27). 
simply means there is no violation of the ECHR. It is not a justified or excused violation. The crucial point for the State is to ensure that it does not fall outside the acceptable margin.

The HRC maintains that it does not afford States an MoA. It can thus be seen that the critical issue is ultimately the point at which the violation is determined to be. ${ }^{271}$ On this analysis the significance of the ECtHR's use of the MoA is as an explanatory or justificatory device for where that point of violation should be located. Assume that there is a case concerning essentially the same right and permissible limitations under both the ECHR and the ICCPR. Both the ECtHR and the HRC determine that there is no violation. The ECtHR says it falls within the States MoA so there is no violation, while the HRC simply states there is no violation. The end result is the same. However, via the MoA the ECtHR can offer States more guidance and explanatory reasoning to States in terms of how close the State is or is not to violating the ECHR. Thus in the series of cases concerning transsexuals the ECtHR warned the UK that it had to stay abreast of scientific research and understanding and respond accordingly with legislative review. ${ }^{272}$

If the MoA was being used by the ECtHR to justify what the HRC would consider to be violations of the equivalent rights in the ICCPR then it would of course be problematic. ${ }^{273}$ However, as submitted, this misunderstands the role and function of the MoA.

\section{The Non-Use of MoA by HRC Is Rhetorical}

A fourth possible explanation is that the HRC's opposition to the MoA is just rhetorical and the HRC has, as James Crawford once suggested, been 'speaking silently the language of the margin'. ${ }^{274}$ In a famous early case in 1982, Hertzberg $v$ Finland ${ }^{275}$ the HRC expressly used the MoA. The case concerned restrictions on expression justified by reference to public morals. The HRC stated that, "public morals differ widely. There is no universally applicable moral standard. Consequently, in this respect, a certain margin of discretion must be accorded to the responsible national authorities. ${ }^{276}$ That remains the only express use of the MoA by the HRC. However, in practice the HRC does recognize that there can be differences between States and flexibility in the interpretation of ICCPR rights and remedies. The national

\footnotetext{
271 For a critique of the violations approach, particularly its narrowness and levelling down effect, see Brems (n 146).

272 See (n 82). Similarly in Dubská and Krejzová (n 74), the ECtHR underlined that the Czech authorities should keep the relevant provisions under a constant review, taking into account medical, scientific and legal developments relating to home births, at para 100.

273 The cases considered in Section VIII(2) above could be analysed on this basis.

274 J Crawford, Preface to Arai-Takahashi (n 1).

275 Cmn No 61/1979, para 10.3. See also VRMB v Canada, Cmn No 236/1987, para 6.3 (it is not for HRC to test a sovereign State's evaluation of an alien's security rating).

276 Cmn No 61/1979, para 10.3 .
} 
context of the case can be critical to an assessment of whether rights have been violated. ${ }^{277}$ For example, the legal protection or measures a society or a State can afford to the family can vary from country to country and depend on different social economic, political and cultural conditions. ${ }^{278}$ Similarly, the concept of the 'family' can differ in some respects from State to State. ${ }^{279}$

As noted, the HRC has been clear that there is no MoA for States with respect to the determination of whether a member of a minority has been denied his right to enjoy his own culture under Article 27. ${ }^{280}$ However, it has accepted that measures that have a certain limited impact on the way of life of persons belonging to a minority will not necessarily amount to a 'denial' of the right under Article 27. ${ }^{281}$ States have thereby been afforded considerable room to authorize economic developments that have had an impact on Article 27 rights. ${ }^{282}$ Where the ECtHR has had to consider similar issues, although framed within the context of Article 8 ECHR (private life), as in Noack $v$ Germany $^{283}$ it has essentially analysed the same issues. It has looked at legitimate aim, necessity, proportionality, impact and stressed the importance of deliberative processes, consultation and continuing protection. Its conclusions reference the MoA but the substance of the approach is arguably the same. ${ }^{284}$ So it could be that HRC effectively affords States an MoA, but it just does not use the rhetorical language of the MoA. ${ }^{285}$ If so, it is offering States less guidance and explanatory reasoning to States than the ECtHR in terms of how close the State is or is not to the point of violating the ICCPR.

\section{E. Lack of Trust in Decisions Made by States Parties}

A fifth explanation might proceed along supposedly undiplomatic but realpolitik lines. European States have accepted substantial inroads into their

\footnotetext{
277 See Mahuika v New Zealand, Cmn No 547/1993 (Fisheries Settlement and its enactment through legislation, including the Quota Management System, were compatible with art 27 with respect to Maori population); A. K. and A. R. v Uzbekistan, Cmn No 1233/2003, (restrictions on freedom of expression were concerned with a perceived threat to national security, via violent overthrow of the constitutional order, and to the rights of others. The HRC could not conclude that the restrictions imposed were incompatible with art 19(3)); Borzov v Estonia, Cmn No 1136/ 2002, para 7.3 (HRC's role in reviewing the existence and relevance of national security considerations depended on the circumstances of the case and the relevant provision of the Covenant. The refusal to grant B citizenship on national security grounds did not violate art 26).

278 Aumeeruddy-Cziffra v Mauritius, Cmn No 35/1978, para 9.2(b)(ii).

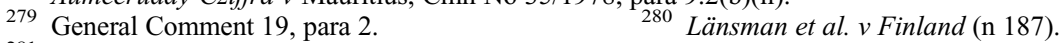

281 ibid. No violation was found.

282 See Lansman v Finland, Cmn No 671/95 (no violation); Lansman v Finland, Cmn No 1023/ 2001 (no violation); Aarela and Nakkalajarvi v Finland, Cmn No 779/97 (no violation); Howard v Canada, Cmn No 879/1999 (no violation). A violation was found in Poma Poma v Peru, Cmn No $1457 / 2006$ (P's way of life and culture had been substantively compromised and there had been no consultation).

283 A. 46346/99), 25 May 2000, admissibility decision, Rep. 2000-VI.

284 See also G. and E. v Norway, A. 9278/81 and 9415/81, Commission (3 October 1983), DR 35, p 30; Buckley v UK, A. 20348/92, (1996); Chapman v the United Kingdom, A. 27238/95, (2001); Connors $v$ United Kingdom, A. 66746/01 (2004). $\quad 285$ See Schmidt (n 192) 656-8.
} 
sovereignty via the now compulsory jurisdiction of the ECtHR (and the even greater inroads via membership of the European Union). In return, so the argument goes, the ECtHR can afford States parties an MoA because it can trust their national authorities to take democratically based decisions. ${ }^{286}$ Decisions in many States in Europe are indeed reached on the basis of commendable democratic processes. Their functioning democratic basis is undoubtedly stronger than in other parts of the world. Three articles of the $\operatorname{ICCPR}(14,21$ and 22) specifically refer to restrictions which can be imposed in a 'democratic society'. However, to only apply the MoA on the precondition of a functioning democracy would be problematic. It is Eurocentric and rather condescending. The ECtHR has a massive caseload and continues to find many democratic States to have violated fundamental rights in the ECHR, including non-derogable rights. Many findings of violation of the ECHR are based on a lack of proportionality in the democratically adopted measures. Classification into democratic and non-democratic States would be difficult in the absence of universally accepted indicators. ${ }^{287}$ But on any basis there are now many functioning democracies outside of Europe. Some diversity between in the ranges of national decisions in their interpretation of rights, each carrying degrees of democratic legitimacy, would be a normal consequence. To not afford a degree of deference via the MoA to those decisions because of the undemocratic nature of previous regimes or undemocratic regimes in other States seems indefensible. Moreover, a condition of democracy in a State is reached via transition and process. Indeed, democratic standards continue to vary considerable across the members of the Council of Europe, particularly after the expansion eastwards. ${ }^{288}$

Moreover, non-European States are, arguably, even more fiercely defensive of their sovereignty and their domestic jurisdiction than European States. They may also be members of regional organizations but their monitoring and enforcements systems are generally weaker than under the ECHR. Basing an MoA on trusting the democratic credentials of States would create a real risk of double standards. States have the primary responsibility to protect international human rights. States should be able to have their human rights defences, for example based on necessity, proportionality, practicability, resources - indeed all of the kinds of issues looked at by the $\mathrm{HRC}$ - and judged on the merits, without any preconceptions of lack of trust or lack of democratic credentials. There is also the question of what to do with the 46 European democracies that are also parties to both the ECHR and the ICCPR. Presumably there is no question of

286 cf Ni Aolain (n 7) 114.

287 See Freedom in the World 2014, Freedom House's annual country-by-country report on global political rights and civil liberties, available at $<$ https://freedomhouse.org/report/freedomworld/freedom-world-2014\#.VIWhPE1yaUk>; GL Munck, Measuring Democracy (John Hopkins Univ 2009); T Landman, Human Rights and Democracy (Bloomsbury 2013).

${ }^{288}$ See Sweeney (n 31); L Hammer and F Emmert, The European Convention on the Human Rights and Fundamental Freedoms in Central and Eastern Europe (Eleven 2011). 
having a differentiated approach for them or for other States adjudged, a priori, to have high democratic standards. ${ }^{289}$ Of course, in assessing an individual case, considerable weight could be afforded to exacting and pertinent reviews, by both parliamentary and judicial bodies. But that is just a matter of evidential weight. The more States take account of human rights standards in coming to a decision the more likely it is that they will comply with those standards.

X. CONCLUDING COMMENTS: TOWARDS A UNIVERSAL APPLICATION OF THE MARGIN OF APPRECIATION

It is submitted that when properly understood the MoA is a complex, sophisticated and defensible intellectual instrument ${ }^{290}$ for international bodies supervising polycentric rights claims. ${ }^{291}$ It is like a multi-dimensional chess game in which a lot of pieces are in play along a number of axes. The MoA factors may combine and interact in different ways, sometimes pulling in different directions in the context of a single case. This complexity and uncertainty may not satisfy jurisprudential purists or pure universalists. But if it represents a sensible pragmatic legal doctrine for a system applying to 47 States and over 820 million people, then why not to a system applying to 168 States and something close to six billion people. The consequence of affording States an MoA is that an acceptable and human-rights-compliant overall balance can be achieved in a number of ways. Thus conceived the MoA plays a crucial role in building a complex multi-level community amongst the 47 Council of Europe States. It could play the same role for wider community of States parties to the ICCPR.

We have considered various explanations for the lack of use of MoA by HRC. ${ }^{292}$ Views will differ on their validity and credibility. Some of the explanations appear more political than legal. However, in terms of harmonization of international human rights law, it remains problematic that the central conceptual doctrine in the ECHR institutional and jurisprudential architecture is ignored by the HRC. In doing so it is submitted that they deprive themselves of a credible and defensible intellectual instrument for making human rights determinations. The MoA could assist the HRC to mediate between the idea of universal human rights and leaving space for reasonable disagreement, legitimate differences, and national or local cultural diversity. ${ }^{293}$ It would thus represent a principled response to many of the Third World critiques of Eurocentrism and universalism. ${ }^{294}$ If the refusal is rhetorical rather than substantive, it is submitted that it would be better if

\footnotetext{
289 cf Ni Aolain (n 7).

290 See also Legg (n 1) who strongly supports the use of the MoA; Carozza (n 103).

291 See G Webber, 'Proportionality, Balancing, and the Cult of Constitutional Rights Scholarship' (2010) 23 Canadian Journal of Law and Jurisprudence 179.

292 See Section IX above.

293 See Legg (n 1) on 'affording appropriate respect for local values in the states' implementation of their international human rights obligations', 225. 
they openly acknowledged the doctrine. But on the evidence of its consistent practice, the HRC's refusal to afford States a MoA, is viewed as substantive rather than rhetorical. At the very least, as a universal human rights body, the HRC should be obliged to explain and justify in the clearest terms jurisprudence which knowingly departs from regional standards. ${ }^{295}$ If the ECtHR, which applies an MoA, still attracts charges of human rights imperialism and an anti-democratic critique, ${ }^{296}$ the HRC would appear to leave itself open for even greater criticism on that account.

On the basis of the evidence and arguments considered in this article it is submitted that the central justifications for the MoA under the ECHR considered in Section IV of this article-subsidiarity, democratic societies and democratic legitimation, institutional competence and comity, and the purpose of establishing minimum rather than harmonized (international as distinct from regional) human rights standards apply with equal if not greater force to the ICCPR. Thus the HRC should afford States parties an MoA. If anything, one might have thought that, given the greater diversity of 168 States parties across the world, as compared to the relative homogeneity of the members of the Council of Europe, ${ }^{297}$ there was an even stronger case for the HRC applying the MoA than the ECtHR. Both logically, empirically and intuitively, a mechanism at an international level needs to have more flexibility than one at any regional one. If the universal system imposed higher universal standards, because it does not allow States an MoA, it makes the regional systems appear problematic. ${ }^{298}$ This is because regional systems are not seen as a challenge to universal human rights as long as they have higher minimum standards than the universal ones. ${ }^{299}$ The HRC also has to accommodate a greater plurality of legal orders based on elements of religious and customary law ${ }^{300}$ and a large number of complex federal-type States and multiple variations thereof.

Obviously there would be some issues of concern in affording States parties to the ICCPR an MoA which can be affected by presence or absence of consensus. First, the much larger number of States concerned (168 parties to ICCPR as compared to 47 parties to ECHR). Second, the even greater massive political, social, economic and legal disparities between them than

295 On whether conflicting interpretation is problematic or not see M Ajevski (ed), 'Fragmentation in International Human Rights Law - Beyond Conflict of Laws' (2014) 32 Nordic Journal of Human Rights 87-175 (Special Issue).

296 Hoffman (n 140); Sumption (n 140 and n 167). The critique is not confined to the UK. In recent years the ECtHR's judgments have led to major public debates in the Netherlands, Germany and Russian Federation.

297 See Donoho (n 178). $\quad 298$ See the cases discussed in Section VIIIB above.

299 See generally D Shelton and PG Carozza, Regional Protection of Human Rights (2nd edn, OUP 2013).

300 On the compatibility of a State's acceptance de facto or de jure of religious and/or customary law within its territory see H Quane, 'Legal Pluralism and International Human Rights Law: Inherently Incompatible, Mutually Reinforcing or Something in Between?' (2013) Oxford Journal of Legal Studies 675; When Legal Worlds Overlap: Human Rights, State and Non-State Law (International Council on Human Rights Policy 2009). 
between members of the Council of Europe. Third, the risk that State consensus might not reflect the rights of sub-State groups and communities. ${ }^{301}$ Fourth, there is arguably a greater risk or likelihood that the MOA doctrine could be used more to confirm prevailing social norms than to challenge them. ${ }^{302}$ Fifth, the HRC, and the Treaty Bodies generally, are more politicized in their composition than the ECtHR. This could be the underlying reason why there is a reluctance to create space for MoA reasoning since it is more liable to be abused. The pressure of the broader political framework within the UN is still very strong and allowing an MoA might then become a problem in that context. Unless its application is clearly reasoned and articulated, its use might also increase perceptions of bias and politicization. These are issues to which States have been and continue to be particularly sensitive. ${ }^{303}$

To an extent some of these difficulties were faced with and dealt by the ECtHR as the scope of the ECHR expanded eastwards. Moreover, some of these difficulties may be inherent in a universal system and so can't be avoided. Moreover, it is submitted that the MoA is a sufficiently sophisticated and flexible instrument of supervision to take account of these risks. As noted, its application can be sensitive to special historical or political considerations, the relative importance of the interest at stake, sensitive moral or ethical issues, the balancing of private and public interests, and complex scientific and technical issues. Assessing all of these kinds of factors cannot be avoided so their explicit acknowledgement would make for more open and transparent reasoning. Finally, it remains to note that many of the arguments considered in this article would apply with equal force to the Inter-American ${ }^{304}$ and African regional human rights systems. ${ }^{305}$ In neither of those regional human rights systems has the concept of affording States parties an MoA been explicitly embraced.

301 GL Neuman, Subsidiarity' in D Shelton (ed), The Oxford Handbook of International Human Rights Law (OUP 2013) 360, 375-7.

302 See E Heinze, Sexual Orientation: A Human Right (Nijhoff 1995) 289, n 32. He also observed that 'If United Nations bodies should ever adopt such a doctrine, seeking favorable developments in a significant number of States before recognizing rights, sexual minorities will have a long wait' at 290.

303 cf R Fredman, The UN Human Rights Council (Routledge 2013).

304 See G Candia, 'Comparing Diverse Approaches to the Margin of Appreciation: The Case of the European and the Inter-American Court of Human Rights' (9 March 2014), available at <http:// papers.ssrn.com/sol3/papers.cfm?abstract_id=2406705>; Contreras (n 261) (arguing that the InterAmerican Court of Human Rights should afford States an MoA); Neuman (n 211); D McGoldrick, 'Affording States a Margin of Appreciation: Comparing the European Court of Human Rights and the Inter-American Court of Human Rights' in P Leach et al., Harmonisation of International Human Rights Standards (Brill 2015) (forthcoming).

305 See H Rubasha, 'Accommodating Diversity: Is the Doctrine of Margin of Appreciation as Applied in the European Court of Human Rights Relevant in the African Human Rights System?', 27 October 2006, available at <http://repository.up.ac.za/bitstream/handle/2263/1228/ rubasha_h_1.pdf? sequence $=1>$. The African Commission on Human Rights exceptionally recognized the substance of the MoA principle in Prince v South Africa, Cmn No 255/2002 (2004): 'the margin of appreciation doctrine informs the African Charter ...', para 51. Prince subsequently complained to the HRC which also found no violation, Prince $v$ South Africa, Cmn No $1474 / 2006$. 